\title{
Mitochondrial dysfunction and oxidative stress in Parkinson's disease
}

\author{
Sudhakar Raja Subramaniam and Marie-Francoise Chesselet \\ Department of Neurology, David Geffen School of Medicine, UCLA, 710 Westwood Plaza, Los \\ Angeles, CA 90095-1769, USA
}

\begin{abstract}
Parkinson's disease is a movement disorder that is characterized by the progressive degeneration of dopaminergic neurons in substantia nigra pars compacta resulting in dopamine deficiency in the striatum. Although majority of the PD cases are sporadic several genetic mutations have also been linked to the disease thus providing new opportunities to study the pathology of the illness. Studies in humans and various animal models of PD reveal that mitochondrial dysfunction might be a defect that occurs early in PD pathogenesis and appears to be a widespread feature in both sporadic and monogenic forms of PD. The general mitochondrial abnormalities linked with the disease include mitochondrial electron transport chain impairment, alterations in mitochondrial morphology and dynamics, mitochondrial DNA mutations and anomaly in calcium homeostasis. Mitochondria are vital organelles with multiple functions and their dysfunction can lead to a decline in energy production, generation of reactive oxygen species and induction of stressinduced apoptosis. In this review, we give an outline of mitochondrial functions that are affected in the pathogenesis of sporadic and familial PD, and hence provide insights that might be valuable for focused future research to exploit possible mitochondrial targets for neuroprotective interventions in PD.
\end{abstract}

\section{Introduction}

Parkinson's disease (PD) is the most common movement disorder and the second most prevalent neurodegenerative disorder worldwide, affecting $\sim 2 \%$ of population over the age of 65. PD is pathologically characterized by: (i) the loss of dopaminergic neurons in substantia nigra pars compacta leading to decreased dopamine levels in the basal ganglia and (ii) the formation of Lewy bodies - intracytoplasmic inclusions containing fibrillar asynuclein (Spillantini et al., 1997). It is believed that dopamine loss causes dysregulation of the basal ganglia circuitries resulting in prominent clinical motor symptoms including bradykinesia, resting tremor, rigidity and postural instability. In addition to the motor symptoms, non-motor symptoms such as sleep disturbances, depression, cognitive deficits, and autonomic and sensory dysfunction are also well documented in PD (Perez and Palmiter, 2005, Choi et al., 2008, McDowell and Chesselet, 2012).

The etiology of PD has been the focus of research for several decades and considerable advances have been made in understanding the genetic and environmental factors, and the

(C) 2013 Elsevier Ltd. All rights reserved.

Corresponding author: Dr. Marie-Francoise Chesselet, mchesselet@mednet.ucla.edu, Phone: 001-310-267-1781.

Publisher's Disclaimer: This is a PDF file of an unedited manuscript that has been accepted for publication. As a service to our customers we are providing this early version of the manuscript. The manuscript will undergo copyediting, typesetting, and review of the resulting proof before it is published in its final citable form. Please note that during the production process errors may be discovered which could affect the content, and all legal disclaimers that apply to the journal pertain. 
underlying molecular mechanisms of the disease. PD was considered to have no genetic links for nearly a century until a few decades ago, when large-scale linkage analysis studies on PD patients exposed mutations in several different genes. The mutations in the following genes are associated to familial PD: a-synuclein (PARK1/4), parkin (PARK2), PINK1 (PARKG), DJ-1 (PARK7), LRRK2 (PARK8) and ATP13A2 (PARK9) whereas more rarely associated genes include $P A R K 3$, UCHL1 (PARK5), GIGYF2 (PARK11), HTRA2 (PARK13) and PLA2G6 (PARK14), which may represent risk factors rather than causative mutations (Schapira, 2011). Despite the recent advancements in PD genetics, the etiology of PD remains not completely understood. In fact a majority ( $\sim 95 \%$ ) of the PD cases is sporadic and are believed to result from complex interactions between genetic susceptibility and environmental factors. In spite of their differing etiology, sporadic and monogenic PD cases share common biochemical, pathological and clinical features. Mitochondrial dysfunction is one such feature observed in both forms of PD. Since mitochondrial complex I deficiency was first identified in PD brains by Schapira and colleagues in 1989 (Schapira et al., 1989), numerous studies have implicated mitochondrial dysfunction in PD pathogenesis. In this review, we summarize current knowledge on the role of mitochondrial dysfunction in the pathology of sporadic and monogenic PD.

\section{Mitochondrial complex I deficiency and oxidative stress in sporadic PD}

Mitochondria produce ATP (adenosine triphosphate) through the process of respiration and oxidative phosphorylation thereby acting as the primary source of energy in the cell. The process of oxidative phosphorylation involves coupling of both redox and phosphorylation reactions in the inner membrane of mitochondria resulting in effective ATP synthesis. During this process, electrons from NADH (nicotinamide adenine dinucleotide) or $\mathrm{FADH}_{2}$ (flavin adenine dinucleotide) are transported through the electron transport chain (ETC), comprising of complexes I-IV, to create a proton gradient across the inner mitochondrial membrane. The consequent movement of the protons from the mitochondrial matrix to the intermembrane space creates an electrochemical gradient. This electrochemical gradient consists of a pH gradient $(\Delta \mathrm{pH})$ and an electrical gradient $(\Delta \psi)$ that drives the synthesis of ATP from ADP (adenosine diphosphate) through the enzyme ATP synthase (complex V).

Mounting evidence suggests that mitochondria are the primary source of reactive oxygen species that may contribute to intracellular oxidative stress (Starkov, 2008, Murphy, 2009). In the process of oxidative phosphorylation, complex I (NADH-quinone oxidoreductase) acts as the entry point for electrons from the mitochondrial matrix into the ETC by catalyzing the electron transfer from NADH into the ETC subunits. Complex I and to a smaller extent complex III in the ETC are considered to be the main sites of ROS production in mitochondria. Superoxide radical is the primary ROS produced in mitochondria as a result of single electron transfer to oxygen in the respiratory chain. Superoxide dismutase 2 or MnSOD converts superoxide radical to hydrogen peroxide which is further detoxified by the enzyme catalase. However, in the presence of metal ions such as $\mathrm{Fe}^{2+}$, hydrogen peroxide may be converted into a highly reactive hydroxyl radical as a result of Fenton reaction which causes severe oxidative damage to the cellular components. The production of superoxide is believed to be dependent on factors such as the concentration of electron donors, localized oxygen concentration and the second order rate kinetics between them (Starkov, 2008, Murphy, 2009). In mitochondrial complex I, the following conditions lead to the production of superoxide radicals: (i) low ATP production, consequent high protonmotive force $(\Delta \mathrm{pH}$ and $\Delta \psi)$ and a reduced coenzyme Q pool; and (ii) high NADH/NAD ${ }^{+}$ ratio in the mitochondrial matrix. On the other hand, mitochondria with normal ATP production, subsequent low proton-motive force and low $\mathrm{NADH} / \mathrm{NAD}^{+}$ratio in the mitochondrial matrix produce much lesser superoxide radical (Murphy, 2009). In addition to the above conditions, ROS formation in complex I is also significantly increased during the 
reverse electron transport process. Reverse electron transport takes place when there is a reduction of ubiquinone pool that forces electrons uphill from ubiquinol into complex I under high proton-motive force conditions (Winklhofer and Haass, 2010).

Increased stress resulting from ROS production is one of the proposed mechanisms for the death of dopaminergic neurons in PD and mitochondrial complex I is considered to be one of the primary sources of ROS. Disease-specific reduction in mitochondrial complex I activity or protein level in the postmortem substantia nigra of patients with idiopathic PD has been known for a long time (Schapira et al., 1990, Hattori et al., 1991). A study using purified mitochondria also showed a mitochondrial complex I deficiency in the frontal cortex of PD patients (Parker et al., 2008). Mild deficits in complex I activity were also detected in the striatum (Mizuno et al., 1989), cortical brain tissue (Parker et al., 2008), fibroblasts (Mytilineou et al., 1994), blood platelets (Krige et al., 1992, Haas et al., 1995) and rather variably, in skeletal muscle (Blin et al., 1994) and lymphocytes (Yoshino et al., 1992, Haas et al., 1995) of PD patients. Catalytic subunits of complex I were found to contain oxidized proteins and a correlation between increased protein oxidation and reduction in electron transfer capacity was observed in PD patients indicating that oxidative damage to these subunits may result in complex I impairment (Keeney et al., 2006). Interestingly, a recent study shows that the levels of oxidized coenzyme Q-10 and 8hydroxy-2'-deoxyguanosine in cerebrospinal fluid of PD patients were significantly increased suggesting a role for mitochondrial oxidative damage and oxidative DNA damage in PD pathology (Isobe et al., 2010). In addition, a reduction in complex I activity was observed in cytoplasmic hybrid (cybrid) cell lines that contain mitochondrial DNA from sporadic PD patients (Swerdlow et al., 2001).

Interestingly, a mouse model with complex I deficiency that lacked the Ndufs4 gene, one of the 49 subunits of complex I, appeared healthy until 5 weeks but developed progressive encephalomyopathy at 7 weeks of age leading to death. Ndufs 4 knockout mouse showed a reduction in complex I driven oxygen consumption and intact complex I protein levels suggesting that Ndufs4 may facilitate the assembly or stabilization of complex I. On the contrary, total oxygen consumption and ATP levels were at normal levels in these mice (Kruse et al., 2008). The lack of nigrostriatal degeneration in these mice could be due to the fact that the Ndufs4 knockout mouse does not reflect the aging pathology of PD where there is a gradual loss of complex I activity over a long period of time. However midbrain mesencephalic neuron cultures from Ndufs4 knockout mice did not show loss of dopaminergic neurons despite the lack complex I activity. Although dopaminergic neuron were more susceptible to rotenone, MPP+ or paraquat, their lack of complex I activity did not protect from these toxin suggesting that dopaminergic cell death induced by these toxins may not solely be due to their effect on of complex I but also include other effects, for example on the microtubules (Choi et al., 2008). A recent study also reported that tissuespecific knockout of Ndufs4 gene in mid-brain dopaminergic neurons showed no obvious neurodegeneration or loss of striatal innervations or symptoms of parkinsonism, although impairment in dopamine homeostasis and increase in dopamine metabolites were observed in these mice. Ndufs 4 dopaminergic neuron knockouts did not develop a loss of nigrostriatal neuron but not surprisingly, were more vulnerable to neurotoxicity induced by the mitochondrial complex 1 toxin MPTP (Sterky et al., 2012). These data suggest that complex 1 deficiency could contribute to the demise of dopaminergic neurons in the presence of other toxic factors.

Rotenone, a mitochondrial toxin, can induce the loss of dopaminergic neurons, and this toxicity was significantly attenuated by methylene blue, a compound that functions as an alternative electron carrier that by-passes complex I/III blockade emphasizing the role of complex 1 deficiency in rotenone-induced toxicity (Wen et al., 2011). It has been known 
that loss of dopamine homeostasis can affect mitochondrial function, and in line with this, another study shows that the redox modifications of dopamine can inhibit mitochondrial respiratory chain complexes. Oxidized dopamine and 3,4-dihydrophenylacetic acid (DOPAC) inhibited complex I and complex II activities in a dose dependent manner whereas reduced dopamine but not DOPAC inhibited complex II activity. These findings reveal the possible downstream targets of dopamine metabolites that could potentially contribute to the susceptibility of dopaminergic neurons in PD (Gautam and Zeevalk, 2011). It is believed that substantia nigra is more vulnerable to complex I dysfunction compared to other brain regions due to the generation of ROS by the nigral dopaminergic neurons during dopamine metabolism (Chinta and Andersen, 2008). In addition, mouse substantia nigra dopaminergic neurons also showed decreased mitochondrial mass compared to the nondopaminergic neurons and the neurons of the ventral tegmental area indicating that this deficit might contribute to the selective vulnerability of these neurons in PD mouse models (Liang et al., 2007). Altogether, these findings suggest that mitochondrial respiratory chain impairment, in particular complex I deficiency and the subsequent increase in ROS production may indirectly or directly contribute to the pathology of sporadic PD.

\section{Mitochondrial DNA mutations}

Mitochondrial DNA (mtDNA) is a double-stranded circular genome, $16.6 \mathrm{~kb}$ in size, and replicates separately from the cell cycle and nuclear DNA replication. MtDNA encodes for 13 proteins all of which are subunits of the mitochondrial respiratory chain complexes. It also codes for 22 tRNAs and 2 rRNAs that are vital for mitochondrial protein synthesis (Reeve et al., 2008). It appears that the close proximity of mtDNA to ROS generated by the respiratory chain dysfunction, and the lack of proficient DNA repair mechanisms and protective histones, makes the mtDNA vulnerable to mutations (Richter et al., 1988, Ozawa, 1997). As discussed in the previous section, reduction in complex I activity increases ROS generation which may affect mtDNA which codes for 7 of the 45 subunits of complex I enzyme. Alteration of mitochondrial metabolism in cells with mtDNA from PD patients showed changes in the microtubular net and autophagic-lysosomal pathway (Cardoso et al., 2012). Although sequencing of the mitochondrial DNA from control and PD patients did not show any characteristic pathogenic mutation responsible for PD (Vives-Bauza et al., 2002), an agedependent increase in mtDNA deletions associated with respiratory chain dysfunction has been observed in the dopaminergic neurons of substantia nigra (Bender et al., 2006b, Kraytsberg et al., 2006). In addition, neurons lacking complex IV (cytochrome c oxidase) showed high mtDNA deletions. These findings reveal that any significant changes to mtDNA composition might directly affect the mitochondrial respiratory chain activity and function. Moreover, somatic mtDNA deletions were slightly higher in substantia nigra of PD patients compared to age-matched controls. However, mtDNA deletions in aged-brains were not seen in other types of neurons such as pyramidal neurons of the cortex, hippocampal neurons or cerebellar Purkinje cells (Bender et al., 2006b, Kraytsberg et al., 2006).

These observations demonstrate that mtDNA deletions are specific to nigral neurons (Bender et al., 2006b) which may increase their susceptibility to oxidative stress and hence contribute to their selective loss in PD. This is supported by studies in MitoPark mice with a conditional knockout in dopaminergic neurons for mitochondrial transcription factor $\mathrm{A}$ (Tfam) gene, which regulates the transcription of mtDNA, showed reduced mtDNA expression and respiratory chain deficiency in midbrain dopaminergic neurons, which led to a progressive impairment of motor function accompanied by intraneural inclusions and loss of dopaminergic neurons (Ekstrand et al., 2007). In addition, MitoPark mice at the age of 67 weeks showed impaired dopamine uptake in striatum and lack of pacemaker activity in the nigral dopaminergic neurons suggesting that nigrostriatal dysfunction precedes parkinsonism-like behavioral deficits in these mice (Good et al., 2011). 
MtDNA replication is also controlled by mtDNA polymerase gamma 1 (POLG1), an enzyme encoded by nuclear DNA. POLG1 is imported into the inner mitochondrial membrane of mitochondria and it is involved in mtDNA synthesis, replication and repair (Filosto et al., 2003). Mitochondrial dysfunction induced by downregulation of the catalytic subunit of mtDNA polymerase in Drosophila resulted in lower respiratory chain activity, premature aging, age-related motor deficits, progressive and cell type-specific neurodegeneration and was alleviated by bypassing respiratory chain deficiencies using alternative oxidase (Humphrey et al., 2012). Mutations in POLG1 lead to severe progressive multisystem disorder including parkinsonism (Luoma et al., 2004). Recently, POLG1 mutations were shown to have strong association with parkinsonism in a Swedish population, further supporting the involvement of mitochondrial dysfunction in PD pathology (Anvret et al., 2010). Taken together, these results indicate that mitochondrial impairment caused by mtDNA mutations and mutations of nuclear encoded mitochondrial proteins might be involved in PD pathogenesis.

\section{Mitochondria and calcium homeostasis}

Calcium is the principle modulator of mitochondria and endoplasmic reticulum (ER). Calcium readily enters the neurons through open pores like L-type Cav 1.3 calcium channels or by activation of N-methyl-D-aspartate (NMDA) receptors. Intracellular calcium levels are mainly regulated by calcium-binding proteins and by metabotropic glutamate receptors (mGluRs) via ER calcium stores. Calcium once inside the cell is transported across the plasma membrane or sequestered in intracellular organelles such as mitochondria and ER. Calcium enters the matrix of mitochondria through (1) a calcium uniporter or (2) mitochondrial-associated membrane (MAM) pores that allow communication with ER and mitochondria directly. Calcium efflux from mitochondria takes place by several mechanisms including mitochondrial sodium/calcium exchanger (NCX) and high conductance ion channels like mitochondrial permeability transition pore (mPTP). mPTP has two conductance states (1) a low conductance state that is reversible and involved in calcium handling and (2) a high conductance state that is irreversible and leads to mitochondrial swelling and leakage of molecules like cytochrome $\mathrm{C}$ that triggers apoptosis.

Interestingly, recent work shows that substantia nigra pars compacta dopaminergic neurons are autonomously active and generate broad, slow action potentials regularly in the absence of synaptic input (Grace and Bunney, 1983). L-type Cav 1.3 calcium channels are used for this pacemaking property (Surmeier, 2007) which is believed to be essential for the maintenance of ambient dopamine concentrations in regions innervated by these neurons, in particular striatum (Romo and Schultz, 1990). While most other neurons depend exclusively on monovalent cation channels for pacemaking, substantia nigra pars compacta dopaminergic neurons also involve ion channels that allow extracellular calcium into the cytoplasm (Ping and Shepard, 1996, Bonci et al., 1998, Puopolo et al., 2007), causing increased intracellular calcium levels (Wilson and Callaway, 2000, Chan et al., 2007). It is reported that calcium entry through L-type channels increases dopamine metabolism in substantia nigra pars compacta dopaminergic neurons thereby shifting cytosolic dopamine concentration to a toxic range with L-DOPA loading (Mosharov et al., 2009). Recent work shows that maintained opening of L-type calcium channels in substantia nigra pars compacta dopaminergic neurons produces a basal mitochondrial oxidant stress accelerated aging and ultimate cell death (Surmeier et al., 2011). Altogether these studies suggest that calcium signaling might contribute to mitochondria oxidant stress in the pathogenesis of PD. 


\section{Environmental toxins, mitochondrial dysfunction and oxidative stress}

\subsection{MPTP}

In the late 1970s, a group of heroin users in the USA developed acute and irreversible parkinsonism after using illicit drugs intravenously. It was later discovered that this was due the neurotoxic effects of the compound MPTP (1-methyl-4-phenyl-1,2,3,6tetrahydropyridine), a by-product in the synthesis of a meperidine analog (Davis et al., 1979, Langston et al., 1983). One of these patients who died 2 years after the onset of parkinsonian symptoms showed degeneration of dopaminergic neurons in the substantia nigra pars compacta without Lewy bodies (Davis et al., 1979). Similar observations were noticed in patients who died 3-16 years after MPTP toxicity (Langston et al., 1999) confirming that MPTP exposure led to the development of parkinsonism. The remarkable resemblance of parkinsonian symptoms after MPTP intoxication to those observed in sporadic PD led to investigating the effects of this neurotoxin in various animal species. MPTP administration to non-human primates reproduced most but not all of the clinical and pathological symptoms (Moratalla et al., 1992, Forno et al., 1993, Hantraye et al., 1993, Varastet et al., 1994), and in mice at least degeneration of dopaminergic neurons was observed (Heikkila et al., 1984). However, rats were resistant and none of the symptoms could be reproduced (Chiueh et al., 1984). Concurrent to the neuropathological studies, the molecular mechanism of MPTP was also studied intensively. It was shown that MPTP actively crosses the blood brain barrier due to its lipophilicity and is oxidized to a toxic molecule, MPP+ (1-methyl-4phenylpyridinium) by monoamine oxidase in the glial cells (Langston et al., 1984, Markey et al., 1984). MPP+ is taken into the dopaminergic neurons by the dopamine transporter and accumulates in the mitochondria. MPP+ inhibits the mitochondrial complex I (Nicklas et al., 1985, Ramsay et al., 1986) in the electron transport chain and thereby disrupts the flow of electrons resulting in decreased ATP production and increased generation of ROS (Hasegawa et al., 1990, Chan et al., 1991, Hantraye et al., 1996, Przedborski et al., 1996, Fabre et al., 1999, Pennathur et al., 1999). The events downstream of complex I inhibition leading to neuronal cell death are still incompletely understood. Nevertheless, various studies showed the involvement of pro-apoptotic pathways which include caspases, p53, Bcl-2 family members and JNK (Przedborski et al., 1992, Hartmann et al., 2000, Hartmann et al., 2001a, Hartmann et al., 2001b, Beal, 2003, Dauer and Przedborski, 2003, Hald and Lotharius, 2005, Perier et al., 2005, Perier et al., 2007). In addition to complex I inhibition, MPTP has also been reported to inhibit mitochondrial complexes III and IV in vitro, adding to the cellular oxidative stress (Desai et al., 1996). Moreover, MPP+ treatment decreased mitochondrial activity and mitochondrial gene expressions in vitro and a similar reduction in expression of mitochondrial genes and tyrosine hydroxylase was observed after MPTP administration in vivo (Piao et al., 2012). In cells exposed to sub-toxic concentrations of MPTP, alterations in mitochondrial proteins such as chaperones, metabolic enzymes, oxidative phosphorylation-related proteins, inner mitochondrial protein (mitofilin) and outer mitochondrial protein (VDAC1) were identified (Burte et al., 2011). Furthermore, another study looked at the overall proteome changes in different regions of mouse brain after MPTP administration and reported a total of 518 proteins showing alterations across all brain regions. Among them, 270 proteins exhibited specific changes only in the striatum and/or the brain region containing substantia nigra indicating that these proteins are associated with the nigrostriatal pathway. A majority of these altered proteins are associated with mitochondrial dysfunction, dopamine signaling, ubiquitin system, calcium signaling, oxidative stress response and apoptosis (Zhang et al., 2010). Evidence that MPTP causes DNA damage in vivo is compatible with these findings (Hoang et al., 2009). Collectively, these findings suggest mechanisms by which MPTP can cause mitochondrial impairment leading to neurotoxicity and loss of nigrostriatal dopaminergic neurons. Whether or not these mechanisms also contribute to the pathogenic process of PD remains a matter of 
debate. Indeed, a number of compounds have been shown to effectively protect dopaminergic neurons from MPTP toxicity in vivo and in vitro, yet none has yet been shown to be neuroprotective in PD patients in clinical studies (Muller et al., 2003, Anonymous, 2007).

\subsection{Rotenone}

Rotenone is a naturally occurring organic compound that has been used as a pesticide for several decades to control unwanted fish populations, in nurseries, and in organic farming. Rotenone is a specific mitochondrial complex I inhibitor which can act systemically due to its high lipophilicity enabling it to readily cross the blood brain barrier and biological membranes independent of any receptor or transporter. Rotenone inhibits mitochondrial complex I by binding to the acceptor end of the enzyme causing an increase in the reduction state of the complex and thus leading to the leakage of electrons that combine with oxygen to form superoxide (Nicholls, 2008). Complex I inhibition by rotenone leads to initiation of several deleterious effects which include generation of ROS resulting in oxidative stress which is attenuated by antioxidants (Sherer et al., 2003), NMDA receptormediated bioenergetic crisis due to reduction in ATP levels and apoptotic or necrotic cell death due to depolarization caused by aberrant opening of the mitochondrial permeability transition pore. Interestingly, recent reports have implicated rotenone in an increased risk of developing PD in humans (Tanner et al., 2011). In rats, chronic intravenous administration of rotenone caused selective nigral dopaminergic neuron loss and a significant reduction in complex I activity (Betarbet et al., 2000). In this study, the rotenone pathology closely resembled sporadic PD in that the neurodegeneration began in the nerve terminals of striatum and progressed to the cell bodies in the substantia nigra. Rotenone toxicity involved oxidative damage to proteins, showed PD-related motor deficits (Fleming et al., 2004) and Lewy body-like inclusions that immunostained for a-synuclein and ubiquitin were observed in the substantia nigra and striatum (Betarbet et al., 2000, Sherer et al., 2003). However, the observations of these studies were limited due to the inconsistency in development of these deficits in rats after rotenone administration, and others confirmed a high rate of variability in rotenone toxicity in rats (Zhu et al., 2004). Altogether, these findings show that generation of ROS and related oxidative stress are one of the key mechanisms involved in rotenone-mediated toxicity and further implicate their role in nigrostriatal dopamine vulnerability.

\subsection{Paraquat and Maneb}

Paraquat (1,1'-dimethyl-4,4'-bipyridinium dichloride) is a commonly used herbicide that is structurally very similar to MPTP and has long been linked to human PD (Shults et al., 1998, Couzin, 2007, Tanner et al., 2011, Wu et al., 2012). Paraquat has a long half-life following systemic administration and causes lipid peroxidation in mouse brain (Prasad et al., 2007). Administration of paraquat caused selective and dose-dependant loss of dopaminergic neurons in the substantia nigra, associated with mild reduction in dopaminergic nerve terminals in the striatum and modest decrease in motor behavior (Brooks et al., 1999, McCormack et al., 2002). Chronic administration of paraquat showed progressive increase in dopaminergic neuron loss and reduction in dopamine levels (Ossowska et al., 2005). Though paraquat is a weak inhibitor of mitochondrial complex I and causes production of ROS, its toxicity on dopaminergic neurons is exerted by a mechanism that is independent of complex I inhibition and dopamine transporter (DAT) (Richardson et al., 2005). Rather, paraquat accumulates in mitochondria (Cocheme and Murphy, 2008) and acts as a potent redox cycler which converts free radicals that interact with molecular oxygen to superoxide and other ROS (Jones and Vale, 2000, Yumino et al., 2002). The redox cycling of paraquat is further confirmed by studies showing that overexpression of SOD (Thiruchelvam et al., 2005) or compounds that mimic SOD 
(Mollace et al., 2003) show protection against the adverse effects of paraquat. Paraquat increases the generation of ROS and also reduces antioxidant enzyme expression in vitro (Yang and Tiffany-Castiglioni, 2005). On the other hand, a reduction in antioxidant enzyme levels leads to increased sensitivity to paraquat (Van Remmen et al., 2004). Another mechanism by which paraquat increases ROS generation in the mitochondria is through its interactions with glutamate which causes excitotoxicity through $\mathrm{Ca}^{2+}$ efflux by depolarization of NMDA receptor channels and activation of non-NMDA receptor channels. This process generates NOS (nitric oxide synthase) and the resulting nitric oxide enters the dopaminergic neurons leading to further mitochondrial dysfunction (Shimizu et al., 2003). Collectively, these studies suggest that paraquat can induce oxidative stress in vitro and in vivo by multiple mechanisms such as ROS generation by inhibition of mitochondrial complex I and redox cycling, and NOS production by interactions with glutamate in mitochondria.

Maneb is a manganese-containing ethylene-bis-dithiocarbamate compound that is used as a fungicide to treat numerous plant diseases. Maneb has been related to development of parkinsonism in humans (Meco et al., 1994) and to an increased risk of developing PD in individuals also exposed to paraquat (Costello et al., 2009, Ritz et al., 2009). Administration of maneb to mouse models induced deficits in motor behavior (Morato et al., 1989) but most studies used a combination of paraquat and maneb to induce nigrostriatal cell death (Thiruchelvam et al., 2002, Saint-Pierre et al., 2006, Kachroo et al., 2010).

Literature on the mechanisms of Maneb toxicity is very limited however it is known that maneb increases the toxic effects of paraquat in mice (Barlow et al., 2005, Roede et al., 2011). Studies show that maneb inhibits proteosome activity in vitro (Zhou et al., 2004, Wang et al., 2006). In addition, maneb has also been shown to inhibit mitochondrial complex III of the electron transport chain resulting in ROS production in isolated mitochondria of rat brain (Zhang et al., 2003) and impaired mitochondrial function in primary mesencephalic neuronal culture (Domico et al., 2006). These observations indicate that maneb could potentiate mitochondrial ROS production by causing mitochondrial dysfunction and inhibiting mitochondrial complex III. These effects may contribute to its ability to increase PD risk in humans (Ritz et al., 2009).

\section{Mitochondrial dysfunction and oxidative stress in monogenic PD}

\section{1 a-synuclein}

Three different missense mutations (A530T, A30P and E46K) and duplication or triplication of the a-synuclein gene (PARK1, SNCA) are associated with autosomal dominant PD (Polymeropoulos et al., 1997, Kruger et al., 1998, Singleton et al., 2003, Zarranz et al., 2004). a-synuclein is a 140-amino acid presynaptic protein expressed in the central nervous system, which is prone to fibrillar aggregation due to its hydrophobic non-amyloid beta component domain. Fibrillar forms of a-synuclein are a major component of the Lewy bodies, hence providing a link between sporadic and familial PD and implicating asynuclein in both forms of the disease. Indeed, this link is further supported by genome-wide association and epidemiological studies (Spillantini and Goedert, 2000, Edwards et al., 2010, Gatto et al., 2010, Huang Y et al., 2011, Ritz et al., 2012, Silva et al., 2012, Wang et al., 2012). a-synuclein fibrils are believed to play a pivotal role in PD pathogenesis due to their toxicity, which may be caused by the intermediate oligomeric forms of a-synuclein rather than by their final aggregates (Lansbury and Lashuel, 2006, Uversky, 2007, Cookson and van der Brug, 2008, Winklhofer et al., 2008). Familial mutations and over-expression of a-synuclein in vitro increase the formation of a-synuclein protofibrils (Conway et al., 1998, Conway et al., 2000, Fredenburg et al., 2007). Administration of mitochondrial toxins to rodents and cell cultures leads to the formation of a-synuclein aggregates and inclusions 
(Betarbet et al., 2000, Fornai et al., 2005). Similarly, inhibition of ubiquitin proteosomal pathway in vitro causes accumulation of unfolded proteins leading to mitochondrial dysfunction and neuronal cell death (Tanaka et al., 2001). The role of protein aggregation and mitochondrial dysfunction in PD pathogenesis has been well documented and recent studies show that these two processes are interlinked and complementary to each other in the pathogenesis. Interestingly, a study investigating mitochondrial a-synuclein in human brain found significant accumulation of a-synuclein in the substantia nigra and striatum of PD patients (Devi et al., 2008). A fraction of cytosolic a-synuclein has been found within the mitochondria in specific regions (Li et al., 2007, Nakamura et al., 2008, Shavali et al., 2008, Zhang et al., 2008). In mice carrying a mutant A53T human a-synuclein gene, mitochondrial accumulation of a-synuclein was observed in tandem with mitochondrial degeneration associated with mtDNA damage and respiratory complex IV impairment leading to neurodegeneration (Martin et al., 2006). Our recent unpublished studies in Thy1aSyn mice overexpressing wild type a-synuclein (Chesselet et al., 2012) showed accumulation of a-synuclein in mitochondria enriched fractions of brain tissue from ventral mesencephalon consisting of substantia nigra, striatum and midcortex. In addition, reduced mitochondrial complex I activity and enhanced lipid peroxidation was observed specifically in substantia nigra tissue compared to striatum and mid-cortex. The same mice exhibit an increase in mitochondrial pathology in nigrostriatal dopaminergic neurons when exposed to low doses of MPTP (Song et al., 2004).

In another recent study decreased expression of mitochondrial chaperone protein tumor necrosis factor receptor associated protein-1 (TRAP1) in Drosophila with mutant A53T human a-synuclein expression caused an increase in agedependent loss of dopaminergic neurons and decrease in dopamine levels, loss of climbing ability and sensitivity to oxidative stress. Over-expression of human TRAP1 rescued this phenotype. Knockdown of TRAP1 in human neuronal cell lines enhanced A53T a-synuclein-induced sensitivity to oxidative stress and, in HEK293 cells, A53T a-synuclein expression reduced mitochondrial complex I activity suggesting a link between a-synuclein and mitochondrial dysfunction (Butler et al., 2012). In transgenic mice overexpressing A30P a-synuclein more than two-fold, selective increase in carbonyl levels of the metabolic proteins carbonic anhydrase 2, alpha-enolase and lactate dehydrogenase 2 were observed (Poon et al., 2005). In addition, expression of A53T a-synuclein in SH-SY5Y cell lines caused increased sensitivity to MPP+ and 6hydroxydopamine which was protected by antioxidants edaravone and (-)epigallocatechin-3-Ogallate respectively (Ma et al., 2010). Similarly, in mouse models overexpressing human a-synuclein the sensitivity of the mice to mitochondrial toxins such as MPTP and paraquat was enhanced (Norris et al., 2007, Thomas and Beal, 2007). On the other hand, mice lacking a-synuclein were resistant to neurotoxicity induced by the toxins MPTP, malonate and 3-nitropropionic acid (Nicklas et al., 1985, Klivenyi et al., 2006, Elm, 2012).

Interaction of a-synuclein with mitochondria in vitro and in isolated mitochondria leads to cytochrome c release, enhanced mitochondrial calcium and nitric oxide, and oxidative modification of mitochondrial components (Parihar et al., 2008). Another study shows that the N-terminal 32 amino acids of human a-synuclein contain cryptic targeting signal that is essential for mitochondrial targeting of a-synuclein. Mitochondria imported a-synuclein is primarily associated with the inner membrane and the accumulation of wild type asynuclein in dopaminergic neurons lead to a reduction in mitochondrial complex I activity and elevated ROS production. Moreover, overexpression of A53T a-synuclein accelerated this effect (Devi et al., 2008). In addition, translocation of a-synuclein to the surface of mitochondria was increased by cytosolic acidification. This translocation takes place rapidly under artificially induced low $\mathrm{pH}$ conditions and as a result of $\mathrm{pH}$ changes during the process of oxidative or metabolic stress, thus indicating a direct role for a-synuclein in 
mitochondrial physiology, especially under pathological conditions (Cole et al., 2008). These findings suggest that protein aggregation and mitochondrial dysfunction act jointly with complementary mechanisms with a-synuclein acting as a modulator of oxidative stress leading to neurodegeneration. Additionally, these results also highlight that both the genetic and biochemical alterations of a-synuclein lead to its increased association with mitochondria and consecutively affect mitochondrial function in the dopaminergic neurons.

\subsection{Parkin}

Mutations in parkin (PARK2) gene were reported to cause autosomal-recessive juvenile parkinsonism (Kitada et al., 1998, Abbas et al., 1999). The parkin gene encodes a 465 amino acid protein which possesses E3 ubiquitin ligase activity and is involved in the proteasomemediated degradation of numerous proteins in vitro (Shimura et al., 2000). Studies show that some of these proteins are deposited in the brains of patients with parkin mutations (Murakami et al., 2004, Periquet et al., 2005). Parkin mediates the polyubiquitination reaction that clears proteins susceptible to aggregation by the process of proteasomal degradation. The loss of E3 ligase activity causes accumulation of toxic protein aggregates leading to autosomal-recessive juvenile parkinsonism (Dawson, 2006). Additionally, mounting evidences show that parkin can also induce proteasomeindependent ubiquitylation (Doss-Pepe et al., 2005, Lim et al., 2005, Fallon et al., 2006, Hampe et al., 2006, Henn et al., 2007) and such modifications are reported to mediate transcriptional regulation, protein trafficking and neuroprotective signaling (Fallon et al., 2006, Mukhopadhyay and Riezman, 2007). Several recent studies show that parkin is localized in the mitochondria and its functions are associated with mitochondria as well. In proliferating SH-SY5Y cells, parkin was found exclusively inside mitochondria where it binds to mitochondrial transcription factor (TFAM) to regulate mitochondrial transcription and replication (Kuroda et al., 2006). Moreover, parkin overexpression in differentiated PC12 cell cultures prevented ceramideinduced mitochondrial swelling and cytochrome c release (Darios et al., 2003). Overexpression of parkin in mice attenuated dopaminergic cell loss induced by MPTP through protection of mitochondria and reduction of a-synuclein (Bian et al., 2012). In contrast, knockdown of parkin gene in Drosophila and animal models exhibit drastic mitochondrial deficits. Drosophila lacking parkin gene exhibit mitochondria associated apoptotic muscle degeneration and high vulnerability to oxidative stress (Greene et al., 2003, Pesah et al., 2004). Drosophila deficient in parkin also showed reduced lifespan that was reversed by chelation of redox active metals, antioxidants and overexpression of superoxide dismutase 1 (Saini et al., 2010). Parkin knockout mice displayed decreased amounts of several proteins involved in mitochondrial function or oxidative stress in addition to an increase in protein oxidation and lipid peroxidation. These mice also exhibited reduction in respiratory complex I and IV subunits consistent with impairment of mitochondrial respiratory capacity in striatum suggesting mitochondrial dysfunction and oxidative damage (Palacino et al., 2004). In parallel, in humans with homozygous parkin mutations, mitochondrial complex I and complex IV activities in leukocytes are impaired (Muftuoglu et al., 2004). Moreover, mice lacking parkin gene show increased sensitivity to mitochondrial toxins such as rotenone (Rosen et al., 2006). Chronic exposure of rats to rotenone induced behavioral impairments that co-related with histopathological changes and tyrosine hydroxylase signaling, decrease in cytoprotective proteins including parkin, DJ-1 and Hsp70, and increase in caspase 9, caspase 3 and ubiquitin (Sonia Angeline et al., 2012). In addition, numerous studies have also established that parkin protects cells against several mitochondrial toxins in various cellular and animal models (Darios et al., 2003, Hyun et al., 2005, Casarejos et al., 2006, Rosen et al., 2006, Vercammen et al., 2006, Henn et al., 2007, Manfredsson et al., 2007, Paterna et al., 2007). A major finding was the demonstration that parkin is recruited to defective mitochondria and is critical for mitochondrial dynamics and autophagy (also see 5.3) (Narendra et al., 2008, Sun et al., 2012). Altogether these results 
indicate that parkin in addition to other functions such as proteasome dependent and independent ubiquitylation is also vital for mitochondrial respiration and function. On the other hand, it is also reported that a parkin deficient mice model on a B6;129S4 genetic background did not show robust signs of parkinsonism including nigrostriatal, cognitive or noradrenergic dysfunction questioning the credibility of the parkin null mice as a model for PD (Perez and Palmiter, 2005).

\subsection{PINK1}

PINK1 (PTEN-induced putative kinase; PARK6) gene mutations are the second most common cause of autosomal recessive, early onset PD after parkin mutations (Valente et al., 2004). PINK1 is a 581 amino acid protein with a highly conserved serine/threonine kinase domain and an N-terminal mitochondrial targeting sequence (Valente et al., 2004, Silvestri et al., 2005). In mitochondria, it has been reported that PINK1 is sub-localized in different regions including inner mitochondrial membrane (Silvestri et al., 2005, Gandhi et al., 2006, Pridgeon et al., 2007), intermembrane space (Silvestri et al., 2005, Pridgeon et al., 2007) and outer mitochondrial membrane (Gandhi et al., 2006). PINK1 knockdown in human dopaminergic neurons and loss of Pink 1 in primary neurons derived from PINK1 knockout mice result in widespread mitochondrial dysfunction including abnormalities in mitochondrial morphology, reduced membrane potential, increased ROS generation and high sensitivity to apoptosis (Wood-Kaczmar et al., 2008). In substantia nigra dopaminergic neurons prepared from PINK1 KO mice brains, fragmented mitochondria were observed in addition to increased basal mitochondria superoxide and hydrogen peroxide-induced ROS generation. Overexpression of PINK1 restored normal mitochondrial morphology and inhibited ROS production indicating the importance of PINK1 in maintaining mitochondrial morphology and protecting neurons from ROS (Wang et al., 2011). In addition, embryonic fibroblasts derived from PINK1 KO mice showed low mitochondrial membrane potential, decreased cellular ATP levels and decline in mitochondrial respiratory activity (Amo et al., 2011). Primary fibroblast cell lines established from PD patients with PINK1 mutation showed a reduced capacity to effectively remove ROS due to decreased expression of antioxidant enzymes including glutathione peroxidase-1, MnSOD, peroxiredoxin-3 and thioredoxin-2 (Maj et al., 2010). PINK1 knockdown in human cell lines displayed defects in mitochondrial morphology and low mitochondrial membrane potential, and these deficits were reversed by wild type PINK1 but not PD-linked PINK1 mutants (Exner et al., 2007). An increased sensitivity to MPP+ toxicity in cortical neurons was observed in the lack of PINK1 function and this effect was attenuated by overexpression of wild type PINK1 (Haque et al., 2008). In Drosophila, studies show that lack of PINK1 resulted in abnormal mitochondrial morphology, loss of nigrostriatal dopaminergic neurons, apoptotic muscle degeneration and enhanced vulnerability to oxidative stress (Clark et al., 2006, Park et al., 2006, Yang et al., 2006). Studies on mice with PINK1 deficiency showed similar mitochondrial deficits including reduction in complex I-IV activity in the striatum and impairment in mitochondrial respiration. PINK1 loss of function also displayed increased exacerbation to mitochondrial respiration when exposed to oxidant hydrogen peroxide and mild heat shock (Gautier et al., 2008). In addition, these mice showed a decline in dopamine release and synaptic plasticity in striatum which is critical for normal physiological function (Kitada et al., 2007). In contrast, in vitro studies on different cell lines show that overexpression of wild type PINK1 inhibited mitochondrial cytochrome c release and prevented neuronal apoptosis (Petit et al., 2005, Wang et al., 2007). In mouse midbrain dopaminergic neurons, overexpression of PINK1 using adenoviral vectors prevented against MPTP-induced neuronal toxicity (Haque et al., 2008). Moreover, it has been shown that dopamine-induced toxicity in PINK1 knockout mice is mediated by mitochondrial permeability transition pore (mPTP) opening which is dependent on ROS production and calcium signaling. Dopamine-induced cell death could be prevented by blocking ROS 
production, supply of respiratory chain substrates and modification of calcium signaling (Gandhi et al., 2012). PINK1 knockout mice showed region-dependent alterations in mitochondrial proteins related to energy metabolism and membrane potential in midbrain, striatum and cerebral cortex. In particular midbrain region, containing the substantia nigra, showed high turnover of defective mitochondria, whereas striatum and cortex compensated for mitophagy non-function by alternative mechanisms. Cerebral cortex tissue also showed low levels of protein oxidation in both wild-type and PINK1 KO mice indicating low ROS production or better protective mechanism in this brain region (Diedrich et al., 2011). Interestingly, in humans with PINK1 mutation mitochondrial defects and respiratory chain abnormalities were observed in the peripheral tissues (Hoepken et al., 2007). In another study, a PD patient with a mutant PINK1 gene showed mitochondrial respiratory abnormalities and ATP synthesis defects in fibroblasts (Piccoli et al., 2008). Overall the observations show that PINK1 mutation affects mitochondrial function, integrity and associated increase in oxidative stress.

Mitochondria are dynamic organelles that are regulated by fusion and fission. These dynamic events are essential for cellular functions such as energy metabolism, quality control mechanisms and regulation of cell death (Benard and Karbowski, 2009, Soubannier and McBride, 2009). Both mitochondrial fusion and fission contribute to mitochondrial quality control, and any dysfunction in mitochondrial repair will affect normal functions such as mtDNA maintenance (Hoppins and Nunnari, 2009), mitochondrial transport (Ishihara et al., 2009) and mitophagy (Twig et al., 2008). The mitochondrial fusion in outer mitochondrial membrane is regulated by mitofusins (MFN1 and MFN2) whereas optic atrophy protein 1 (OPA1) is required for inner mitochondrial membrane fusion (Zorzano et al., 2010). Mitochondrial fission is controlled by dynamin-related protein 1 (DRP1) (Reddy et al., 2011). Studies show that neurons are particularly vulnerable to mitochondrial fusion and fission (Knott and Bossy-Wetzel, 2008, Mattson et al., 2008, Chen and Chan, 2009, Schon and Przedborski, 2011). PINK1 promotes the recruitment of parkin into mitochondria which triggers mitophagy. This process depolarizes the inner mitochondrial membrane and alerts the cell of a damaged organelle, which will eventually be removed (Narendra et al., 2010). In Drosophila, parkin and PINK1 promote mitochondrial fission and/or inhibit fusion by negatively regulating MFN and OPA1 functions, and/or positively regulating DRP1 function (Clark et al., 2006, Deng et al., 2008). In rat hippocampal neurons, overexpression of parkin or PINK1 showed increased mitochondrial number, smaller size and reduced mitochondrial occupancy of neuronal processes indicating the mitochondrial fission/fusion dynamics is tipped toward fission. In converse, PINK1 inactivation resulted in elongated mitochondria suggesting the balance of the mitochondrial dynamics is tipped towards fusion. Moreover, overexpression of the fission protein (DRP1) or knockdown of the fusion protein OPA1 suppressed PINK1-RNAi induced mitochondrial morphological defect, and overexpression of Parkin or PINK1 suppressed elongation of mitochondria caused by DRP1 RNAi. Similarly, PINK1/Parkin influenced mitochondrial dynamics in rat midbrain dopaminergic neurons (Yu et al., 2011). More studies in Drosophila and mammalian cells also underline the role of PINK1-Parkin pathway in controlling mitochondrial dynamics (Poole et al., 2008, Yang et al., 2008, Park et al., 2009). Interestingly, some studies also indicate that mitochondrial fusion proteins play an important neuroprotective role in oxidative stress and mitochondrial stress models (Meuer et al., 2007, Gomez-Lazaro et al., 2008).

\subsection{DJ-1}

Mutations in DJ-1 (PARK7) gene cause rare cases of autosomal recessive, early onset parkinsonism (Bonifati et al., 2003). DJ-1 is a multifunctional 189 amino acid protein with antioxidant and transcription modulation properties. It is believed that under basal 
conditions DJ-1 is localized in the cytosol and to a lesser extent in nucleus and mitochondria (Zhang et al., 2005). However, in oxidative stress conditions DJ-1 translocates to mitochondria, where it is found in the matrix and intermembrane space, and later to the nucleus. This translocation of DJ-1 into the mitochondria and nucleus is associated with its ability to provide neuroprotection (Canet-Aviles et al., 2004, Ashley et al., 2009, Junn et al., 2009). The translocation of DJ-1 is facilitated by the oxidation of cysteine 106 to cysteinesulfinic acid which is vital for DJ-1 function in the mitochondria (Canet-Aviles et al., 2004, Blackinton et al., 2009). In vitro silencing of DJ-1 using siRNA in neuronal cells showed increased cell death induced by oxidative stress, ER stress and inhibition of proteasome (Yokota et al., 2003, Taira et al., 2004). Primary mouse embryonic fibroblasts from DJ-1 KO mice displayed a reduction in mitochondrial transmembrane potential and an increase in mitochondrial permeability transition pore opening both of which were restored by antioxidant treatment. In addition, an increase in production of ROS was observed in these cell lines but the antioxidant enzyme levels remained constant (Giaime et al., 2012). DJ-1 null dopaminergic neurons showed deficiency in mitochondrial complex I activity as a result of defect in the assembly of complex I leading to defective supercomplex formation. These defects were reversed by DJ-1 overexpression indicating the specific role of DJ-1 in mitochondrial dysfunction (Heo et al., 2012). Another study also showed that DJ-1 null cells from mouse embryos exhibit reduced mitochondrial complex I activity that was rescued partially by overexpression of DJ-1 (Kwon et al., 2011). In vitro cell models from DJ-1 KO mice and human carriers of E64D mutation of the DJ-1 gene displayed impaired mitochondrial respiration, enhanced intra-mitochondrial ROS, reduced mitochondrial membrane potential, altered mitochondrial morphology and importantly, accumulation of defective mitochondria (Krebiehl et al., 2010). Additionally, cell lines, cultured neurons, mouse brain and lymphoblast cells derived from DJ-1 deficient patients display abnormal mitochondrial morphology. Mitochondria from DJ-1 deficient mice produce more ROS and scavengers of ROS rescued the phenotype indicating the critical role played by ROS in this model (Irrcher et al., 2010). Mice lacking DJ-1 gene showed nigrostriatal dopaminergic neuronal loss, elevated striatal dopamine levels, enhanced dopamine re-uptake and hypokinesia (Chen et al., 2005, Goldberg et al., 2005). In addition, mice deficient for DJ-1 showed further increased in dopaminergic neuron loss after MPTP administration (Kim et al., 2005). Similarly, administration of paraquat to DJ-1 knockout mice caused dopaminergic system defects and proteasome impairment (Yang et al., 2007). Conversely, overexpression of DJ-1 using viral vectors into the mice nigrostriatal system prevented MPTP-induced dopaminergic neuron loss. In addition, DJ-1 may support mitochondrial function during oxidative stress by interacting with several targets such as PINK1 (Tang et al., 2006) and parkin (Moore et al., 2005). Furthermore, under increased oxidative stress DJ-1 may also be involved in the activation of transcription of Mn-SOD gene, which encodes for the mitochondrial antioxidant enzyme (Zhong and $\mathrm{Xu}, 2008$ ). Altogether, these findings suggest that DJ-1 may prevent protein misfolding and aggregation under oxidative stress conditions.

\subsection{LRRK2}

LRRK2 (Leucine-rich repeat kinase 2; $P A R K 8$ ) mutations are known to cause autosomaldominant PD. These mutations are associated with a majority of familial PD cases and are also linked to sporadic late-onset PD (Paisan-Ruiz et al., 2004, Zimprich et al., 2004, Klein and Schlossmacher, 2006). The LRRK2 gene encodes a 2527 amino acid protein which is a serine/threonine kinase containing a conserved mitogen-activated protein kinase kinase kinase (MAPKKK), a Roc domain with Ras/GTPase, a WD40-repeat domain and leucinerich repeats (Mata et al., 2006, Biskup and West, 2009, Gandhi et al., 2009). Several LRRK2 mutations lead to an increase in LRRK2 kinase activity that was responsible for the neurotoxicity in vitro, suggesting a toxic gain of function mechanism (Gloeckner et al., 2006, Greggio et al., 2006, Smith et al., 2006). Overexpression of LRRK2 mutated proteins 
in vitro leads to apoptotic neuronal cell death that was blocked by caspase inhibitors and required Apaf1 indicating that LRRK2 mutations cause mitochondrial dysfunction (Iaccarino et al., 2007). In cortical neurons the LRRK2 G2019S mutation can cause defects in mitochondrial morphology and dynamics. Expression of LRRK2 also increases production of ROS in cells. In addition, endogenous LRRK2 interacts with Dynamin like protein 1 (DLP1) in neurons and expression of LRRK2 leads to translocation of DLP1 from the cytosol into the mitochondria suggesting a functional role for LRRK2 (Niu et al., 2012). Skin biopsies from PD patients carrying LRRK2 G2019S mutation showed a decrease in mitochondrial membrane potential and low total intracellular ATP levels as a result of mitochondrial dysfunction. Additionally, mitochondrial elongation and interconnectivity were also elevated in LRRK2 G2019S mutant patients indicating that LRRK2 mutations affect mitochondrial function and morphology (Mortiboys et al., 2010). LRRK2 was shown to bind to outer mitochondrial membrane, localized in rat mitochondria by immunohistochemistry and $10 \%$ of overexpressed LRRK2 was found to be associated with the mitochondrial fraction (West et al., 2005, Biskup et al., 2006, Gloeckner et al., 2006). Although knowledge about the physiological function of LRRK2 protein is limited, these studies indicate that the mechanism of LRRK2 mutation toxicity could be associated with mitochondria.

\section{Perspective}

Numerous studies conducted using various genetic and toxin models of PD have contributed to a better understanding of the disease pathogenesis. As detailed in this review, many of these studies point to mitochondrial dysfunction as a common occurrence in both sporadic and monogenic PD, and suggest that it may play a major role in the pathophysiology of the disease. The findings suggest that complex I deficiency and related oxidative stress in addition to mitochondrial DNA mutations are associated with PD pathogenesis. The factors that potentially cause mitochondrial damage in sporadic PD are still unknown. Exposure to environmental factors such as pesticides may cause mitochondrial dysfunction that result in PD in both humans and animal models of PD. In addition, familial mutations in genes can also lead to mitochondrial dysfunction that leads to PD. In PD patients and animal models, the general biochemical abnormalities that are observed in mitochondria include complex I impairment, reduced ATP synthesis, increased ROS production, mitochondrial DNA mutations and defective mitochondrial repair pathways. However, the sequence of events leading to the mitochondrial impairment and degeneration of neurons remains elusive. The studies also indicate that dopaminergic neurons in the substantia nigra are highly vulnerable under stress conditions compared to other neuronal types. High oxidative burden during dopamine metabolism, excitotoxicity, high iron content (Chinta and Andersen, 2008) and low mitochondrial mass (Liang et al., 2007) in substantia nigra dopaminergic neurons compared to other neurons might contribute to its selective vulnerability in stress conditions. In addition, high concentrations of intracellular $\mathrm{Ca}^{2+}$ are also observed in substantia nigra dopaminergic neurons (Wilson and Callaway, 2000, Chan et al., 2007) that contribute to a basal mitochondrial oxidant stress which was specific in substantia nigra dopaminergic neurons and not in neighboring ventral tegmental area nigra dopaminergic neurons (Guzman et al., 2010) .These observations in substantia nigra dopaminergic neurons underline the importance of mitochondrial functions, which are vital for the survival of these neurons, particularly during aging. In view of the vital functions of mitochondria including energy metabolism, calcium homeostasis, cellular quality control and death regulation, it is important to consider mitochondrial dysfunction as one of the major factors that can contribute to dopaminergic neuronal cell death in PD. Given that mitochondrial dysfunction is widespread in both sporadic and monogenic PD, and the current knowledge on the mechanistic aspects of mitochondrial impairment, mitochondria remain attractive targets for the development of neuroprotective strategies for PD. However, clinical trials using 
compounds targeting mitochondria such as coenzyme Q10 (CoQ10) (Shults et al., 1998, Muller et al., 2003, Anonymous, 2007, Storch et al., 2007), an essential cofactor in mitochondrial electron transport chain, and creatine (Bender et al., 2006a), a naturally occurring compound that boosts ATP levels and protects mitochondria have so far showed mild symptomatic or no significant beneficial effect in PD patients. However, reaching sufficient brain concentrations of Co-Q is notoriously difficult. Rather than arguing against the potential of mitochondria-targeted therapies, these results point to the need for developing more effective and specific agents that achieve high brain levels, reduce oxidative stress at its source rather than by quenching reactive oxidative species, and/or improve the removal of defective mitochondria. Nevertheless, it is important to remember that PD is a multifaceted disease and mitochondrial dysfunction might be a part of the complex pathology of the disease. Future neuroprotective therapies will likely need to target multiple pathological pathways including mitochondrial dysfunction.

\section{Acknowledgments}

This work was supported by Public Health Service grant P50 NS38367 (UCLA, Morris K. Udall Parkinson Disease Research Center of Excellence) and P01ES016732 (the UCLA Center for Gene Environment in Parkinson's Disease).

\section{References}

Abbas N, Lucking CB, Ricard S, Durr A, Bonifati V, De Michele G, Bouley S, Vaughan JR, Gasser T, Marconi R, Broussolle E, Brefel-Courbon C, Harhangi BS, Oostra BA, Fabrizio E, Bohme GA, Pradier L, Wood NW, Filla A, Meco G, Denefle P, Agid Y, Brice A. A wide variety of mutations in the parkin gene are responsible for autosomal recessive parkinsonism in Europe. French Parkinson's Disease Genetics Study Group and the European Consortium on Genetic Susceptibility in Parkinson's Disease. Human molecular genetics. 1999; 8:567-574. [PubMed: 10072423]

Amo T, Sato S, Saiki S, Wolf AM, Toyomizu M, Gautier CA, Shen J, Ohta S, Hattori N. Mitochondrial membrane potential decrease caused by loss of PINK1 is not due to proton leak, but to respiratory chain defects. Neurobiology of disease. 2011; 41:111-118. [PubMed: 20817094]

Anonymous. A randomized clinical trial of coenzyme Q10 and GPI-1485 in early Parkinson disease. Neurology. 2007; 68:20-28. [PubMed: 17200487]

Anvret A, Westerlund M, Sydow O, Willows T, Lind C, Galter D, Belin AC. Variations of the CAG trinucleotide repeat in DNA polymerase gamma (POLG1) is associated with Parkinson's disease in Sweden. Neuroscience letters. 2010; 485:117-120. [PubMed: 20826197]

Ashley AK, Hanneman WH, Katoh T, Moreno JA, Pollack A, Tjalkens RB, Legare ME. Analysis of targeted mutation in DJ-1 on cellular function in primary astrocytes. Toxicology letters. 2009; 184:186-191. [PubMed: 19063952]

Barlow BK, Lee DW, Cory-Slechta DA, Opanashuk LA. Modulation of antioxidant defense systems by the environmental pesticide maneb in dopaminergic cells. Neurotoxicology. 2005; 26:63-75. [PubMed: 15527874]

Beal MF. Mitochondria, oxidative damage, and inflammation in Parkinson's disease. Annals of the New York Academy of Sciences. 2003; 991:120-131. [PubMed: 12846981]

Benard G, Karbowski M. Mitochondrial fusion and division: Regulation and role in cell viability. Seminars in cell \& developmental biology. 2009; 20:365-374. [PubMed: 19530306]

Bender A, Koch W, Elstner M, Schombacher Y, Bender J, Moeschl M, Gekeler F, Muller-Myhsok B, Gasser T, Tatsch K, Klopstock T. Creatine supplementation in Parkinson disease: a placebocontrolled randomized pilot trial. Neurology. 2006a; 67:1262-1264. [PubMed: 17030762]

Bender A, Krishnan KJ, Morris CM, Taylor GA, Reeve AK, Perry RH, Jaros E, Hersheson JS, Betts J, Klopstock T, Taylor RW, Turnbull DM. High levels of mitochondrial DNA deletions in substantia nigra neurons in aging and Parkinson disease. Nature genetics. 2006b; 38:515-517. [PubMed: 16604074] 
Betarbet R, Sherer TB, MacKenzie G, Garcia-Osuna M, Panov AV, Greenamyre JT. Chronic systemic pesticide exposure reproduces features of Parkinson's disease. Nature neuroscience. 2000; 3:13011306.

Bian M, Liu J, Hong X, Yu M, Huang Y, Sheng Z, Fei J, Huang F. Overexpression of parkin ameliorates dopaminergic neurodegeneration induced by 1- methyl-4-phenyl-1,2,3,6tetrahydropyridine in mice. PloS one. 2012; 7:e39953. [PubMed: 22792139]

Biskup S, Moore DJ, Celsi F, Higashi S, West AB, Andrabi SA, Kurkinen K, Yu SW, Savitt JM, Waldvogel HJ, Faull RL, Emson PC, Torp R, Ottersen OP, Dawson TM, Dawson VL. Localization of LRRK2 to membranous and vesicular structures in mammalian brain. Annals of neurology. 2006; 60:557-569. [PubMed: 17120249]

Biskup S, West AB. Zeroing in on LRRK2-linked pathogenic mechanisms in Parkinson's disease. Biochimica et biophysica acta. 2009; 1792:625-633. [PubMed: 18973807]

Blackinton J, Lakshminarasimhan M, Thomas KJ, Ahmad R, Greggio E, Raza AS, Cookson MR, Wilson MA. Formation of a stabilized cysteine sulfinic acid is critical for the mitochondrial function of the parkinsonism protein DJ-1. The Journal of biological chemistry. 2009; 284:64766485. [PubMed: 19124468]

Blin O, Desnuelle C, Rascol O, Borg M, Peyro Saint Paul H, Azulay JP, Bille F, Figarella D, Coulom F, Pellissier JF, et al. Mitochondrial respiratory failure in skeletal muscle from patients with Parkinson's disease and multiple system atrophy. Journal of the neurological sciences. 1994; 125:95-101. [PubMed: 7964895]

Bonci A, Grillner P, Mercuri NB, Bernardi G. L-Type calcium channels mediate a slow excitatory synaptic transmission in rat midbrain dopaminergic neurons. The Journal of neuroscience : the official journal of the Society for Neuroscience. 1998; 18:6693-6703. [PubMed: 9712641]

Bonifati V, Rizzu P, van Baren MJ, Schaap O, Breedveld GJ, Krieger E, Dekker MC, Squitieri F, Ibanez P, Joosse M, van Dongen JW, Vanacore N, van Swieten JC, Brice A, Meco G, van Duijn CM, Oostra BA, Heutink P. Mutations in the DJ-1 gene associated with autosomal recessive earlyonset parkinsonism. Science. 2003; 299:256-259. [PubMed: 12446870]

Brooks AI, Chadwick CA, Gelbard HA, Cory-Slechta DA, Federoff HJ. Paraquat elicited neurobehavioral syndrome caused by dopaminergic neuron loss. Brain research. 1999; 823:1-10. [PubMed: 10095006]

Burte F, De Girolamo LA, Hargreaves AJ, Billett EE. Alterations in the mitochondrial proteome of neuroblastoma cells in response to complex 1 inhibition. Journal of proteome research. 2011; 10:1974-1986. [PubMed: 21322648]

Butler EK, Voigt A, Lutz AK, Toegel JP, Gerhardt E, Karsten P, Falkenburger B, Reinartz A, Winklhofer KF, Schulz JB. The mitochondrial chaperone protein TRAP1 mitigates alphaSynuclein toxicity. PLoS genetics. 2012; 8:e1002488. [PubMed: 22319455]

Canet-Aviles RM, Wilson MA, Miller DW, Ahmad R, McLendon C, Bandyopadhyay S, Baptista MJ, Ringe D, Petsko GA, Cookson MR. The Parkinson's disease protein DJ-1 is neuroprotective due to cysteine-sulfinic acid-driven mitochondrial localization. Proceedings of the National Academy of Sciences of the United States of America. 2004; 101:9103-9108. [PubMed: 15181200]

Cardoso SM, Esteves AR, Arduino DM. Mitochondrial metabolic control of microtubule dynamics impairs the autophagic pathway in Parkinson's disease. Neuro-degenerative diseases. 2012; 10:3840. [PubMed: 22156537]

Casarejos MJ, Menendez J, Solano RM, Rodriguez-Navarro JA, Garcia de Yebenes J, Mena MA. Susceptibility to rotenone is increased in neurons from parkin null mice and is reduced by minocycline. Journal of neurochemistry. 2006; 97:934-946. [PubMed: 16573651]

Chan CS, Guzman JN, Ilijic E, Mercer JN, Rick C, Tkatch T, Meredith GE, Surmeier DJ. 'Rejuvenation' protects neurons in mouse models of Parkinson's disease. Nature. 2007; 447:10811086. [PubMed: 17558391]

Chan P, DeLanney LE, Irwin I, Langston JW, Di Monte D. Rapid ATP loss caused by 1-methyl-4phenyl-1,2,3,6-tetrahydropyridine in mouse brain. Journal of neurochemistry. 1991; 57:348-351. [PubMed: 2051170] 
Chen H, Chan DC. Mitochondrial dynamics--fusion, fission, movement, and mitophagy--in neurodegenerative diseases. Human molecular genetics. 2009; 18:R169-R176. [PubMed: 19808793]

Chen L, Cagniard B, Mathews T, Jones S, Koh HC, Ding Y, Carvey PM, Ling Z, Kang UJ, Zhuang X. Age-dependent motor deficits and dopaminergic dysfunction in DJ-1 null mice. The Journal of biological chemistry. 2005; 280:21418-21426. [PubMed: 15799973]

Chesselet MF, Richter F, Zhu C, Magen I, Watson MB, Subramaniam SR. A progressive mouse model of Parkinson's disease: the Thy1-aSyn ("Line 61") mice. Neurotherapeutics : the journal of the American Society for Experimental NeuroTherapeutics. 2012; 9:297-314. [PubMed: 22350713]

Chinta SJ, Andersen JK. Redox imbalance in Parkinson's disease. Biochimica et biophysica acta. 2008; 1780:1362-1367. [PubMed: 18358848]

Chiueh CC, Markey SP, Burns RS, Johannessen JN, Jacobowitz DM, Kopin IJ. Neurochemical and behavioral effects of 1-methyl-4-phenyl-1,2,3,6-tetrahydropyridine (MPTP) in rat, guinea pig, and monkey. Psychopharmacology bulletin. 1984; 20:548-553. [PubMed: 6332333]

Choi WS, Kruse SE, Palmiter RD, Xia Z. Mitochondrial complex I inhibition is not required for dopaminergic neuron death induced by rotenone, MPP+, or paraquat. Proceedings of the National Academy of Sciences of the United States of America. 2008; 105:15136-15141. [PubMed: 18812510]

Clark IE, Dodson MW, Jiang C, Cao JH, Huh JR, Seol JH, Yoo SJ, Hay BA, Guo M. Drosophila pink1 is required for mitochondrial function and interacts genetically with parkin. Nature. 2006; 441:1162-1166. [PubMed: 16672981]

Cocheme HM, Murphy MP. Complex I is the major site of mitochondrial superoxide production by paraquat. The Journal of biological chemistry. 2008; 283:1786-1798. [PubMed: 18039652]

Cole NB, Dieuliis D, Leo P, Mitchell DC, Nussbaum RL. Mitochondrial translocation of alphasynuclein is promoted by intracellular acidification. Experimental cell research. 2008; 314:20762089. [PubMed: 18440504]

Conway KA, Harper JD, Lansbury PT. Accelerated in vitro fibril formation by a mutant alphasynuclein linked to early-onset Parkinson disease. Nature medicine. 1998; 4:1318-1320.

Conway KA, Lee SJ, Rochet JC, Ding TT, Williamson RE, Lansbury PT Jr. Acceleration of oligomerization, not fibrillization, is a shared property of both alpha-synuclein mutations linked to early-onset Parkinson's disease: implications for pathogenesis and therapy. Proceedings of the National Academy of Sciences of the United States of America. 2000; 97:571-576. [PubMed: 10639120]

Cookson MR, van der Brug M. Cell systems and the toxic mechanism(s) of alpha-synuclein. Experimental neurology. 2008; 209:5-11. [PubMed: 17603039]

Costello S, Cockburn M, Bronstein J, Zhang X, Ritz B. Parkinson's disease and residential exposure to maneb and paraquat from agricultural applications in the central valley of California. American journal of epidemiology. 2009; 169:919-926. [PubMed: 19270050]

Couzin J. Clinical research. Testing a novel strategy against Parkinson's disease. Science. 2007; 315:1778. [PubMed: 17395800]

Darios F, Corti O, Lucking CB, Hampe C, Muriel MP, Abbas N, Gu WJ, Hirsch EC, Rooney T, Ruberg M, Brice A. Parkin prevents mitochondrial swelling and cytochrome c release in mitochondria-dependent cell death. Human molecular genetics. 2003; 12:517-526. [PubMed: 12588799]

Dauer W, Przedborski S. Parkinson's disease: mechanisms and models. Neuron. 2003; 39:889-909. [PubMed: 12971891]

Davis GC, Williams AC, Markey SP, Ebert MH, Caine ED, Reichert CM, Kopin IJ. Chronic Parkinsonism secondary to intravenous injection of meperidine analogues. Psychiatry research. 1979; 1:249-254. [PubMed: 298352]

Dawson TM. Parkin and defective ubiquitination in Parkinson's disease. Journal of neural transmission Supplementum. 2006:209-213. [PubMed: 17017531]

Deng H, Dodson MW, Huang H, Guo M. The Parkinson's disease genes pink1 and parkin promote mitochondrial fission and/or inhibit fusion in Drosophila. Proceedings of the National Academy of Sciences of the United States of America. 2008; 105:14503-14508. [PubMed: 18799731] 
Desai VG, Feuers RJ, Hart RW, Ali SF. MPP(+)-induced neurotoxicity in mouse is age-dependent: evidenced by the selective inhibition of complexes of electron transport. Brain research. 1996; 715:1-8. [PubMed: 8739616]

Devi L, Raghavendran V, Prabhu BM, Avadhani NG, Anandatheerthavarada HK. Mitochondrial import and accumulation of alpha-synuclein impair complex I in human dopaminergic neuronal cultures and Parkinson disease brain. The Journal of biological chemistry. 2008; 283:9089-9100. [PubMed: 18245082]

Diedrich M, Kitada T, Nebrich G, Koppelstaetter A, Shen J, Zabel C, Klose J, Mao L. Brain region specific mitophagy capacity could contribute to selective neuronal vulnerability in Parkinson's disease. Proteome science. 2011; 9:59. [PubMed: 21943346]

Domico LM, Zeevalk GD, Bernard LP, Cooper KR. Acute neurotoxic effects of mancozeb and maneb in mesencephalic neuronal cultures are associated with mitochondrial dysfunction. Neurotoxicology. 2006; 27:816-825. [PubMed: 16889834]

Doss-Pepe EW, Chen L, Madura K. Alpha-synuclein and parkin contribute to the assembly of ubiquitin lysine 63-linked multiubiquitin chains. The Journal of biological chemistry. 2005; 280:16619-16624. [PubMed: 15718234]

Edwards TL, Scott WK, Almonte C, Burt A, Powell EH, Beecham GW, Wang L, Zuchner S, Konidari I, Wang G, Singer C, Nahab F, Scott B, Stajich JM, Pericak-Vance M, Haines J, Vance JM, Martin ER. Genome-wide association study confirms SNPs in SNCA and the MAPT region as common risk factors for Parkinson disease. Annals of human genetics. 2010; 74:97-109. [PubMed: 20070850]

Ekstrand MI, Terzioglu M, Galter D, Zhu S, Hofstetter C, Lindqvist E, Thams S, Bergstrand A, Hansson FS, Trifunovic A, Hoffer B, Cullheim S, Mohammed AH, Olson L, Larsson NG. Progressive parkinsonism in mice with respiratorychain-deficient dopamine neurons. Proceedings of the National Academy of Sciences of the United States of America. 2007; 104:1325-1330. [PubMed: 17227870]

Elm JJ. Design innovations and baseline findings in a long-term Parkinson's trial: the National Institute of Neurological Disorders and Stroke Exploratory Trials in Parkinson's Disease Long-Term Study-1. Movement disorders : official journal of the Movement Disorder Society. 2012; 27:15131521. [PubMed: 23079770]

Exner N, Treske B, Paquet D, Holmstrom K, Schiesling C, Gispert S, Carballo-Carbajal I, Berg D, Hoepken HH, Gasser T, Kruger R, Winklhofer KF, Vogel F, Reichert AS, Auburger G, Kahle PJ, Schmid B, Haass C. Loss-of-function of human PINK1 results in mitochondrial pathology and can be rescued by parkin. The Journal of neuroscience : the official journal of the Society for Neuroscience. 2007; 27:12413-12418. [PubMed: 17989306]

Fabre E, Monserrat J, Herrero A, Barja G, Leret ML. Effect of MPTP on brain mitochondrial H2O2 and ATP production and on dopamine and DOPAC in the striatum. Journal of physiology and biochemistry. 1999; 55:325-331. [PubMed: 10731084]

Fallon L, Belanger CM, Corera AT, Kontogiannea M, Regan-Klapisz E, Moreau F, Voortman J, Haber M, Rouleau G, Thorarinsdottir T, Brice A, van Bergen En Henegouwen PM, Fon EA. A regulated interaction with the UIM protein Eps15 implicates parkin in EGF receptor trafficking and PI(3)KAkt signalling. Nature cell biology. 2006; 8:834-842.

Filosto M, Mancuso M, Nishigaki Y, Pancrudo J, Harati Y, Gooch C, Mankodi A, Bayne L, Bonilla E, Shanske S, Hirano M, DiMauro S. Clinical and genetic heterogeneity in progressive external ophthalmoplegia due to mutations in polymerase gamma. Archives of neurology. 2003; 60:12791284. [PubMed: 12975295]

Fleming SM, Salcedo J, Fernagut PO, Rockenstein E, Masliah E, Levine MS, Chesselet MF. Early and progressive sensorimotor anomalies in mice overexpressing wild-type human alpha-synuclein. The Journal of neuroscience : the official journal of the Society for Neuroscience. 2004; 24:94349440. [PubMed: 15496679]

Fornai F, Schluter OM, Lenzi P, Gesi M, Ruffoli R, Ferrucci M, Lazzeri G, Busceti CL, Pontarelli F, Battaglia G, Pellegrini A, Nicoletti F, Ruggieri S, Paparelli A, Sudhof TC. Parkinson-like syndrome induced by continuous MPTP infusion: convergent roles of the ubiquitin-proteasome system and alphasynuclein. Proceedings of the National Academy of Sciences of the United States of America. 2005; 102:3413-3418. [PubMed: 15716361] 
Forno LS, DeLanney LE, Irwin I, Langston JW. Similarities and differences between MPTP-induced parkinsonsim and Parkinson's disease. Neuropathologic considerations. Advances in neurology. 1993; 60:600-608. [PubMed: 8380528]

Fredenburg RA, Rospigliosi C, Meray RK, Kessler JC, Lashuel HA, Eliezer D, Lansbury PT Jr. The impact of the E46K mutation on the properties of alphasynuclein in its monomeric and oligomeric states. Biochemistry. 2007; 46:7107-7118. [PubMed: 17530780]

Gandhi PN, Chen SG, Wilson-Delfosse AL. Leucine-rich repeat kinase 2 (LRRK2): a key player in the pathogenesis of Parkinson's disease. Journal of neuroscience research. 2009; 87:1283-1295. [PubMed: 19025767]

Gandhi S, Muqit MM, Stanyer L, Healy DG, Abou-Sleiman PM, Hargreaves I, Heales S, Ganguly M, Parsons L, Lees AJ, Latchman DS, Holton JL, Wood NW, Revesz T. PINK1 protein in normal human brain and Parkinson's disease. Brain : a journal of neurology. 2006; 129:1720-1731. [PubMed: 16702191]

Gandhi S, Vaarmann A, Yao Z, Duchen MR, Wood NW, Abramov AY. Dopamine induced neurodegeneration in a PINK1 model of Parkinson's disease. PloS one. 2012; 7:e37564. [PubMed: 22662171]

Gatto NM, Rhodes SL, Manthripragada AD, Bronstein J, Cockburn M, Farrer M, Ritz B. alphaSynuclein gene may interact with environmental factors in increasing risk of Parkinson's disease. Neuroepidemiology. 2010; 35:191-195. [PubMed: 20664293]

Gautam AH, Zeevalk GD. Characterization of reduced and oxidized dopamine and 3,4dihydrophenylacetic acid, on brain mitochondrial electron transport chain activities. Biochimica et biophysica acta. 2011; 1807:819-828. [PubMed: 21463600]

Gautier CA, Kitada T, Shen J. Loss of PINK1 causes mitochondrial functional defects and increased sensitivity to oxidative stress. Proceedings of the National Academy of Sciences of the United States of America. 2008; 105:11364-11369. [PubMed: 18687901]

Giaime E, Yamaguchi H, Gautier CA, Kitada T, Shen J. Loss of DJ-1 Does Not Affect Mitochondrial Respiration but Increases ROS Production and Mitochondrial Permeability Transition Pore Opening. PloS one. 2012; 7:e40501. [PubMed: 22792356]

Gloeckner CJ, Kinkl N, Schumacher A, Braun RJ, O'Neill E, Meitinger T, Kolch W, Prokisch H, Ueffing M. The Parkinson disease causing LRRK2 mutation I2020T is associated with increased kinase activity. Human molecular genetics. 2006; 15:223-232. [PubMed: 16321986]

Goldberg MS, Pisani A, Haburcak M, Vortherms TA, Kitada T, Costa C, Tong Y, Martella G, Tscherter A, Martins A, Bernardi G, Roth BL, Pothos EN, Calabresi P, Shen J. Nigrostriatal dopaminergic deficits and hypokinesia caused by inactivation of the familial Parkinsonism-linked gene DJ-1. Neuron. 2005; 45:489-496. [PubMed: 15721235]

Gomez-Lazaro M, Bonekamp NA, Galindo MF, Jordan J, Schrader M. 6-Hydroxydopamine (6OHDA) induces Drp1-dependent mitochondrial fragmentation in SH-SY5Y cells. Free radical biology \& medicine. 2008; 44:1960-1969. [PubMed: 18395527]

Good CH, Hoffman AF, Hoffer BJ, Chefer VI, Shippenberg TS, Backman CM, Larsson NG, Olson L, Gellhaar S, Galter D, Lupica CR. Impaired nigrostriatal function precedes behavioral deficits in a genetic mitochondrial model of Parkinson's disease. FASEB journal : official publication of the Federation of American Societies for Experimental Biology. 2011; 25:1333-1344. [PubMed: 21233488]

Grace AA, Bunney BS. Intracellular and extracellular electrophysiology of nigral dopaminergic neurons--2. Action potential generating mechanisms and morphological correlates. Neuroscience. 1983; 10:317-331. [PubMed: 6633864]

Greene JC, Whitworth AJ, Kuo I, Andrews LA, Feany MB, Pallanck LJ. Mitochondrial pathology and apoptotic muscle degeneration in Drosophila parkin mutants. Proceedings of the National Academy of Sciences of the United States of America. 2003; 100:4078-4083. [PubMed: 12642658]

Greggio E, Jain S, Kingsbury A, Bandopadhyay R, Lewis P, Kaganovich A, van der Brug MP, Beilina A, Blackinton J, Thomas KJ, Ahmad R, Miller DW, Kesavapany S, Singleton A, Lees A, Harvey RJ, Harvey K, Cookson MR. Kinase activity is required for the toxic effects of mutant LRRK2/ dardarin. Neurobiology of disease. 2006; 23:329-341. [PubMed: 16750377] 
Guzman JN, Sanchez-Padilla J, Wokosin D, Kondapalli J, Ilijic E, Schumacker PT, Surmeier DJ. Oxidant stress evoked by pacemaking in dopaminergic neurons is attenuated by DJ-1. Nature. 2010; 468:696-700. [PubMed: 21068725]

Haas RH, Nasirian F, Nakano K, Ward D, Pay M, Hill R, Shults CW. Low platelet mitochondrial complex I and complex II/III activity in early untreated Parkinson's disease. Annals of neurology. 1995; 37:714-722. [PubMed: 7778844]

Hald A, Lotharius J. Oxidative stress and inflammation in Parkinson's disease: is there a causal link? Experimental neurology. 2005; 193:279-290. [PubMed: 15869932]

Hampe C, Ardila-Osorio H, Fournier M, Brice A, Corti O. Biochemical analysis of Parkinson's disease-causing variants of Parkin, an E3 ubiquitin-protein ligase with monoubiquitylation capacity. Human molecular genetics. 2006; 15:2059-2075. [PubMed: 16714300]

Hantraye P, Brouillet E, Ferrante R, Palfi S, Dolan R, Matthews RT, Beal MF. Inhibition of neuronal nitric oxide synthase prevents MPTP-induced parkinsonism in baboons. Nature medicine. 1996; 2:1017-1021.

Hantraye P, Varastet M, Peschanski M, Riche D, Cesaro P, Willer JC, Maziere M. Stable parkinsonian syndrome and uneven loss of striatal dopamine fibres following chronic MPTP administration in baboons. Neuroscience. 1993; 53:169-178. [PubMed: 8469305]

Haque ME, Thomas KJ, D'Souza C, Callaghan S, Kitada T, Slack RS, Fraser P, Cookson MR, Tandon A, Park DS. Cytoplasmic Pink1 activity protects neurons from dopaminergic neurotoxin MPTP. Proceedings of the National Academy of Sciences of the United States of America. 2008; 105:1716-1721. [PubMed: 18218782]

Hartmann A, Hunot S, Michel PP, Muriel MP, Vyas S, Faucheux BA, Mouatt-Prigent A, Turmel H, Srinivasan A, Ruberg M, Evan GI, Agid Y, Hirsch EC. Caspase-3: A vulnerability factor and final effector in apoptotic death of dopaminergic neurons in Parkinson's disease. Proceedings of the National Academy of Sciences of the United States of America. 2000; 97:2875-2880. [PubMed: 10688892]

Hartmann A, Michel PP, Troadec JD, Mouatt-Prigent A, Faucheux BA, Ruberg M, Agid Y, Hirsch EC. Is Bax a mitochondrial mediator in apoptotic death of dopaminergic neurons in Parkinson's disease? Journal of neurochemistry. 2001a; 76:1785-1793. [PubMed: 11259496]

Hartmann A, Troadec JD, Hunot S, Kikly K, Faucheux BA, Mouatt-Prigent A, Ruberg M, Agid Y, Hirsch EC. Caspase-8 is an effector in apoptotic death of dopaminergic neurons in Parkinson's disease, but pathway inhibition results in neuronal necrosis. The Journal of neuroscience : the official journal of the Society for Neuroscience. 2001b; 21:2247-2255. [PubMed: 11264300]

Hasegawa E, Takeshige K, Oishi T, Murai Y, Minakami S. 1-Methyl-4-phenylpyridinium (MPP+) induces NADH-dependent superoxide formation and enhances NADH-dependent lipid peroxidation in bovine heart submitochondrial particles. Biochemical and biophysical research communications. 1990; 170:1049-1055. [PubMed: 2167668]

Hattori N, Tanaka M, Ozawa T, Mizuno Y. Immunohistochemical studies on complexes I, II, III, and IV of mitochondria in Parkinson's disease. Annals of neurology. 1991; 30:563-571. [PubMed: 1665052]

Heikkila RE, Hess A, Duvoisin RC. Dopaminergic neurotoxicity of 1-methyl-4-phenyl-1,2,5,6tetrahydropyridine in mice. Science. 1984; 224:1451-1453. [PubMed: 6610213]

Henn IH, Bouman L, Schlehe JS, Schlierf A, Schramm JE, Wegener E, Nakaso K, Culmsee C, Berninger B, Krappmann D, Tatzelt J, Winklhofer KF. Parkin mediates neuroprotection through activation of IkappaB kinase/nuclear factor-kappaB signaling. The Journal of neuroscience : the official journal of the Society for Neuroscience. 2007; 27:1868-1878. [PubMed: 17314283]

Heo JY, Park JH, Kim SJ, Seo KS, Han JS, Lee SH, Kim JM, Park JI, Park SK, Lim K, Hwang BD, Shong M, Kweon GR. DJ-1 null dopaminergic neuronal cells exhibit defects in mitochondrial function and structure: involvement of mitochondrial complex I assembly. PloS one. 2012; 7:e32629. [PubMed: 22403686]

Hoang T, Choi DK, Nagai M, Wu DC, Nagata T, Prou D, Wilson GL, Vila M, Jackson-Lewis V, Dawson VL, Dawson TM, Chesselet MF, Przedborski S. Neuronal NOS and cyclooxygenase-2 contribute to DNA damage in a mouse model of Parkinson disease. Free radical biology \& medicine. 2009; 47:1049-1056. [PubMed: 19616617] 
Hoepken HH, Gispert S, Morales B, Wingerter O, Del Turco D, Mulsch A, Nussbaum RL, Muller K, Drose S, Brandt U, Deller T, Wirth B, Kudin AP, Kunz WS, Auburger G. Mitochondrial dysfunction, peroxidation damage and changes in glutathione metabolism in PARK6. Neurobiology of disease. 2007; 25:401-411. [PubMed: 17141510]

Hoppins S, Nunnari J. The molecular mechanism of mitochondrial fusion. Biochimica et biophysica acta. 2009; 1793:20-26. [PubMed: 18691613]

Huang Y, Rowe DB, GM H. Interaction between a-Synuclein and Tau Genotypes and the Progression of Parkinson's Disease. Journal of Parkinson's Disease. 2011; 1:271-276.

Humphrey DM, Parsons RB, Ludlow ZN, Riemensperger T, Esposito G, Verstreken P, Jacobs HT, Birman S, Hirth F. Alternative oxidase rescues mitochondriamediated dopaminergic cell loss in Drosophila. Human molecular genetics. 2012; 21:2698-2712. [PubMed: 22398207]

Hyun DH, Lee M, Halliwell B, Jenner P. Effect of overexpression of wild-type or mutant parkin on the cellular response induced by toxic insults. Journal of neuroscience research. 2005; 82:232-244. [PubMed: 16130151]

Iaccarino C, Crosio C, Vitale C, Sanna G, Carri MT, Barone P. Apoptotic mechanisms in mutant LRRK2-mediated cell death. Human molecular genetics. 2007; 16:1319-1326. [PubMed: 17409193]

Irrcher I, Aleyasin H, Seifert EL, Hewitt SJ, Chhabra S, Phillips M, Lutz AK, Rousseaux MW, Bevilacqua L, Jahani-Asl A, Callaghan S, MacLaurin JG, Winklhofer KF, Rizzu P, Rippstein P, Kim RH, Chen CX, Fon EA, Slack RS, Harper ME, McBride HM, Mak TW, Park DS. Loss of the Parkinson's disease-linked gene DJ-1 perturbs mitochondrial dynamics. Human molecular genetics. 2010; 19:3734-3746. [PubMed: 20639397]

Ishihara N, Nomura M, Jofuku A, Kato H, Suzuki SO, Masuda K, Otera H, Nakanishi Y, Nonaka I, Goto Y, Taguchi N, Morinaga H, Maeda M, Takayanagi R, Yokota S, Mihara K. Mitochondrial fission factor Drp1 is essential for embryonic development and synapse formation in mice. Nature cell biology. 2009; 11:958-966.

Isobe $\mathrm{C}$, Abe T, Terayama Y. Levels of reduced and oxidized coenzyme Q-10 and 8-hydroxy-2'deoxyguanosine in the cerebrospinal fluid of patients with living Parkinson's disease demonstrate that mitochondrial oxidative damage and/or oxidative DNA damage contributes to the neurodegenerative process. Neuroscience letters. 2010; 469:159-163. [PubMed: 19944739]

Jones GM, Vale JA. Mechanisms of toxicity, clinical features, and management of diquat poisoning: a review. Journal of toxicology Clinical toxicology. 2000; 38:123-128. [PubMed: 10778908]

Junn E, Jang WH, Zhao X, Jeong BS, Mouradian MM. Mitochondrial localization of DJ-1 leads to enhanced neuroprotection. Journal of neuroscience research. 2009; 87:123-129. [PubMed: 18711745]

Kachroo A, Irizarry MC, Schwarzschild MA. Caffeine protects against combined paraquat and manebinduced dopaminergic neuron degeneration. Experimental neurology. 2010; 223:657-661. [PubMed: 20188092]

Keeney PM, Xie J, Capaldi RA, Bennett JP Jr. Parkinson's disease brain mitochondrial complex I has oxidatively damaged subunits and is functionally impaired and misassembled. The Journal of neuroscience : the official journal of the Society for Neuroscience. 2006; 26:5256-5264. [PubMed: 16687518]

Kim RH, Smith PD, Aleyasin H, Hayley S, Mount MP, Pownall S, Wakeham A, You-Ten AJ, Kalia SK, Horne P, Westaway D, Lozano AM, Anisman H, Park DS, Mak TW. Hypersensitivity of DJ-1-deficient mice to 1-methyl-4-phenyl-1,2,3,6-tetrahydropyrindine (MPTP) and oxidative stress. Proceedings of the National Academy of Sciences of the United States of America. 2005; 102:5215-5220. [PubMed: 15784737]

Kitada T, Asakawa S, Hattori N, Matsumine H, Yamamura Y, Minoshima S, Yokochi M, Mizuno Y, Shimizu N. Mutations in the parkin gene cause autosomal recessive juvenile parkinsonism. Nature. 1998; 392:605-608. [PubMed: 9560156]

Kitada T, Pisani A, Porter DR, Yamaguchi H, Tscherter A, Martella G, Bonsi P, Zhang C, Pothos EN, Shen J. Impaired dopamine release and synaptic plasticity in the striatum of PINK1-deficient mice. Proceedings of the National Academy of Sciences of the United States of America. 2007; 104:11441-11446. [PubMed: 17563363] 
Klein C, Schlossmacher MG. The genetics of Parkinson disease: Implications for neurological care. Nature clinical practice Neurology. 2006; 2:136-146.

Klivenyi P, Siwek D, Gardian G, Yang L, Starkov A, Cleren C, Ferrante RJ, Kowall NW, Abeliovich A, Beal MF. Mice lacking alpha-synuclein are resistant to mitochondrial toxins. Neurobiology of disease. 2006; 21:541-548. [PubMed: 16298531]

Knott AB, Bossy-Wetzel E. Impairing the mitochondrial fission and fusion balance: a new mechanism of neurodegeneration. Annals of the New York Academy of Sciences. 2008; 1147:283-292. [PubMed: 19076450]

Kraytsberg Y, Kudryavtseva E, McKee AC, Geula C, Kowall NW, Khrapko K. Mitochondrial DNA deletions are abundant and cause functional impairment in aged human substantia nigra neurons. Nature genetics. 2006; 38:518-520. [PubMed: 16604072]

Krebiehl G, Ruckerbauer S, Burbulla LF, Kieper N, Maurer B, Waak J, Wolburg H, Gizatullina Z, Gellerich FN, Woitalla D, Riess O, Kahle PJ, Proikas-Cezanne T, Kruger R. Reduced basal autophagy and impaired mitochondrial dynamics due to loss of Parkinson's disease-associated protein DJ-1. PloS one. 2010; 5:e9367. [PubMed: 20186336]

Krige D, Carroll MT, Cooper JM, Marsden CD, Schapira AH. Platelet mitochondrial function in Parkinson's disease. The Royal Kings and Queens Parkinson Disease Research Group. Annals of neurology. 1992; 32:782-788. [PubMed: 1471869]

Kruger R, Kuhn W, Muller T, Woitalla D, Graeber M, Kosel S, Przuntek H, Epplen JT, Schols L, Riess O. Ala30Pro mutation in the gene encoding alphasynuclein in Parkinson's disease. Nature genetics. 1998; 18:106-108. [PubMed: 9462735]

Kruse SE, Watt WC, Marcinek DJ, Kapur RP, Schenkman KA, Palmiter RD. Mice with mitochondrial complex I deficiency develop a fatal encephalomyopathy. Cell metabolism. 2008; 7:312-320. [PubMed: 18396137]

Kuroda Y, Mitsui T, Kunishige M, Shono M, Akaike M, Azuma H, Matsumoto T. Parkin enhances mitochondrial biogenesis in proliferating cells. Human molecular genetics. 2006; 15:883-895. [PubMed: 16449237]

Kwon HJ, Heo JY, Shim JH, Park JH, Seo KS, Ryu MJ, Han JS, Shong M, Son JH, Kweon GR. DJ-1 mediates paraquat-induced dopaminergic neuronal cell death. Toxicology letters. 2011; 202:8592. [PubMed: 21300143]

Langston JW, Ballard P, Tetrud JW, Irwin I. Chronic Parkinsonism in humans due to a product of meperidine-analog synthesis. Science. 1983; 219:979-980. [PubMed: 6823561]

Langston JW, Forno LS, Tetrud J, Reeves AG, Kaplan JA, Karluk D. Evidence of active nerve cell degeneration in the substantia nigra of humans years after 1-methyl-4-phenyl-1,2,3,6tetrahydropyridine exposure. Annals of neurology. 1999; 46:598-605. [PubMed: 10514096]

Langston JW, Irwin I, Langston EB, Forno LS. 1-Methyl-4-phenylpyridinium ion (MPP+): identification of a metabolite of MPTP, a toxin selective to the substantia nigra. Neuroscience letters. 1984; 48:87-92. [PubMed: 6332288]

Lansbury PT, Lashuel HA. A century-old debate on protein aggregation and neurodegeneration enters the clinic. Nature. 2006; 443:774-779. [PubMed: 17051203]

Li WW, Yang R, Guo JC, Ren HM, Zha XL, Cheng JS, Cai DF. Localization of alpha-synuclein to mitochondria within midbrain of mice. Neuroreport. 2007; 18:1543-1546. [PubMed: 17885598]

Liang CL, Wang TT, Luby-Phelps K, German DC. Mitochondria mass is low in mouse substantia nigra dopamine neurons: implications for Parkinson's disease. Experimental neurology. 2007; 203:370-380. [PubMed: 17010972]

Lim KL, Chew KC, Tan JM, Wang C, Chung KK, Zhang Y, Tanaka Y, Smith W, Engelender S, Ross CA, Dawson VL, Dawson TM. Parkin mediates nonclassical, proteasomal-independent ubiquitination of synphilin-1: implications for Lewy body formation. The Journal of neuroscience : the official journal of the Society for Neuroscience. 2005; 25:2002-2009. [PubMed: 15728840]

Luoma P, Melberg A, Rinne JO, Kaukonen JA, Nupponen NN, Chalmers RM, Oldfors A, Rautakorpi I, Peltonen L, Majamaa K, Somer H, Suomalainen A. Parkinsonism, premature menopause, and mitochondrial DNA polymerase gamma mutations: clinical and molecular genetic study. Lancet. 2004; 364:875-882. [PubMed: 15351195] 
Ma L, Cao TT, Kandpal G, Warren L, Fred Hess J, Seabrook GR, Ray WJ. Genome-wide microarray analysis of the differential neuroprotective effects of antioxidants in neuroblastoma cells overexpressing the familial Parkinson's disease alpha-synuclein A53T mutation. Neurochemical research. 2010; 35:130-142. [PubMed: 19649707]

Maj MC, Tkachyova I, Patel P, Addis JB, Mackay N, Levandovskiy V, Lee J, Lang AE, Cameron JM, Robinson BH. Oxidative stress alters the regulatory control of p66Shc and Akt in PINK1 deficient cells. Biochemical and biophysical research communications. 2010; 399:331-335. [PubMed: 20637729]

Manfredsson FP, Burger C, Sullivan LF, Muzyczka N, Lewin AS, Mandel RJ. rAAV-mediated nigral human parkin over-expression partially ameliorates motor deficits via enhanced dopamine neurotransmission in a rat model of Parkinson's disease. Experimental neurology. 2007; 207:289-301. [PubMed: 17678648]

Markey SP, Johannessen JN, Chiueh CC, Burns RS, Herkenham MA. Intraneuronal generation of a pyridinium metabolite may cause drug-induced parkinsonism. Nature. 1984; 311:464-467. [PubMed: 6332988]

Martin LJ, Pan Y, Price AC, Sterling W, Copeland NG, Jenkins NA, Price DL, Lee MK. Parkinson's disease alpha-synuclein transgenic mice develop neuronal mitochondrial degeneration and cell death. The Journal of neuroscience : the official journal of the Society for Neuroscience. 2006; 26:41-50. [PubMed: 16399671]

Mata IF, Wedemeyer WJ, Farrer MJ, Taylor JP, Gallo KA. LRRK2 in Parkinson's disease: protein domains and functional insights. Trends in neurosciences. 2006; 29:286-293. [PubMed: 16616379]

Mattson MP, Gleichmann M, Cheng A. Mitochondria in neuroplasticity and neurological disorders. Neuron. 2008; 60:748-766. [PubMed: 19081372]

McCormack AL, Thiruchelvam M, Manning-Bog AB, Thiffault C, Langston JW, Cory-Slechta DA, Di Monte DA. Environmental risk factors and Parkinson's disease: selective degeneration of nigral dopaminergic neurons caused by the herbicide paraquat. Neurobiology of disease. 2002; 10:119127. [PubMed: 12127150]

McDowell K, Chesselet MF. Animal models of the non-motor features of Parkinson's disease. Neurobiology of disease. 2012; 46:597-606. [PubMed: 22236386]

Meco G, Bonifati V, Vanacore N, Fabrizio E. Parkinsonism after chronic exposure to the fungicide maneb (manganese ethylene-bis-dithiocarbamate). Scandinavian journal of work, environment \& health. 1994; 20:301-305.

Meuer K, Suppanz IE, Lingor P, Planchamp V, Goricke B, Fichtner L, Braus GH, Dietz GP, Jakobs S, Bahr M, Weishaupt JH. Cyclin-dependent kinase 5 is an upstream regulator of mitochondrial fission during neuronal apoptosis. Cell death and differentiation. 2007; 14:651-661. [PubMed: 17218957]

Mizuno Y, Ohta S, Tanaka M, Takamiya S, Suzuki K, Sato T, Oya H, Ozawa T, Kagawa Y. Deficiencies in complex I subunits of the respiratory chain in Parkinson's disease. Biochemical and biophysical research communications. 1989; 163:1450-1455. [PubMed: 2551290]

Mollace V, Iannone M, Muscoli C, Palma E, Granato T, Rispoli V, Nistico R, Rotiroti D, Salvemini D. The role of oxidative stress in paraquat-induced neurotoxicity in rats: protection by non peptidyl superoxide dismutase mimetic. Neuroscience letters. 2003; 335:163-166. [PubMed: 12531458]

Moore DJ, Zhang L, Troncoso J, Lee MK, Hattori N, Mizuno Y, Dawson TM, Dawson VL. Association of DJ-1 and parkin mediated by pathogenic DJ-1 mutations and oxidative stress. Human molecular genetics. 2005; 14:71-84. [PubMed: 15525661]

Moratalla R, Quinn B, DeLanney LE, Irwin I, Langston JW, Graybiel AM. Differential vulnerability of primate caudate-putamen and striosome-matrix dopamine systems to the neurotoxic effects of 1-methyl-4-phenyl-1,2,3,6-tetrahydropyridine. Proceedings of the National Academy of Sciences of the United States of America. 1992; 89:3859-3863. [PubMed: 1570304]

Morato GS, Lemos T, Takahashi RN. Acute exposure to maneb alters some behavioral functions in the mouse. Neurotoxicology and teratology. 1989; 11:421-425. [PubMed: 2593980] 
Mortiboys H, Johansen KK, Aasly JO, Bandmann O. Mitochondrial impairment in patients with Parkinson disease with the G2019S mutation in LRRK2. Neurology. 2010; 75:2017-2020. [PubMed: 21115957]

Mosharov EV, Larsen KE, Kanter E, Phillips KA, Wilson K, Schmitz Y, Krantz DE, Kobayashi K, Edwards RH, Sulzer D. Interplay between cytosolic dopamine, calcium, and alpha-synuclein causes selective death of substantia nigra neurons. Neuron. 2009; 62:218-229. [PubMed: 19409267]

Muftuoglu M, Elibol B, Dalmizrak O, Ercan A, Kulaksiz G, Ogus H, Dalkara T, Ozer N. Mitochondrial complex I and IV activities in leukocytes from patients with parkin mutations. Movement disorders : official journal of the Movement Disorder Society. 2004; 19:544-548. [PubMed: 15133818]

Mukhopadhyay D, Riezman H. Proteasome-independent functions of ubiquitin in endocytosis and signaling. Science. 2007; 315:201-205. [PubMed: 17218518]

Muller T, Buttner T, Gholipour AF, Kuhn W. Coenzyme Q10 supplementation provides mild symptomatic benefit in patients with Parkinson's disease. Neuroscience letters. 2003; 341:201204. [PubMed: 12697283]

Murakami T, Shoji M, Imai Y, Inoue H, Kawarabayashi T, Matsubara E, Harigaya Y, Sasaki A, Takahashi R, Abe K. Pael-R is accumulated in Lewy bodies of Parkinson's disease. Annals of neurology. 2004; 55:439-442. [PubMed: 14991825]

Murphy MP. How mitochondria produce reactive oxygen species. The Biochemical journal. 2009; 417:1-13. [PubMed: 19061483]

Mytilineou C, Werner P, Molinari S, Di Rocco A, Cohen G, Yahr MD. Impaired oxidative decarboxylation of pyruvate in fibroblasts from patients with Parkinson's disease. Journal of neural transmission Parkinson's disease and dementia section. 1994; 8:223-228.

Nakamura K, Nemani VM, Wallender EK, Kaehlcke K, Ott M, Edwards RH. Optical reporters for the conformation of alpha-synuclein reveal a specific interaction with mitochondria. The Journal of neuroscience : the official journal of the Society for Neuroscience. 2008; 28:12305-12317. [PubMed: 19020024]

Narendra D, Tanaka A, Suen DF, Youle RJ. Parkin is recruited selectively to impaired mitochondria and promotes their autophagy. The Journal of cell biology. 2008; 183:795-803. [PubMed: 19029340]

Narendra DP, Jin SM, Tanaka A, Suen DF, Gautier CA, Shen J, Cookson MR, Youle RJ. PINK1 is selectively stabilized on impaired mitochondria to activate Parkin. PLoS biology. 2010; 8:e1000298. [PubMed: 20126261]

Nicholls DG. Oxidative stress and energy crises in neuronal dysfunction. Annals of the New York Academy of Sciences. 2008; 1147:53-60. [PubMed: 19076430]

Nicklas WJ, Vyas I, Heikkila RE. Inhibition of NADH-linked oxidation in brain mitochondria by 1methyl-4-phenyl-pyridine, a metabolite of the neurotoxin, 1-methyl-4-phenyl-1,2,5,6tetrahydropyridine. Life sciences. 1985; 36:2503-2508. [PubMed: 2861548]

Niu J, Yu M, Wang C, Xu Z. Leucine-rich repeat kinase 2 disturbs mitochondrial dynamics via Dynamin-like protein. Journal of neurochemistry. 2012; 122:650-658. [PubMed: 22639965]

Norris EH, Uryu K, Leight S, Giasson BI, Trojanowski JQ, Lee VM. Pesticide exposure exacerbates alpha-synucleinopathy in an A53T transgenic mouse model. The American journal of pathology. 2007; 170:658-666. [PubMed: 17255333]

Ossowska K, Wardas J, Smialowska M, Kuter K, Lenda T, Wieronska JM, Zieba B, Nowak P, Dabrowska J, Bortel A, Kwiecinski A, Wolfarth S. A slowly developing dysfunction of dopaminergic nigrostriatal neurons induced by long-term paraquat administration in rats: an animal model of preclinical stages of Parkinson's disease? The European journal of neuroscience. 2005; 22:1294-1304. [PubMed: 16190885]

Ozawa T. Oxidative damage and fragmentation of mitochondrial DNA in cellular apoptosis. Bioscience reports. 1997; 17:237-250. [PubMed: 9337479]

Paisan-Ruiz C, Jain S, Evans EW, Gilks WP, Simon J, van der Brug M, Lopez de Munain A, Aparicio S, Gil AM, Khan N, Johnson J, Martinez JR, Nicholl D, Carrera IM, Pena AS, de Silva R, Lees A, Marti-Masso JF, Perez-Tur J, Wood NW, Singleton AB. Cloning of the gene containing 
mutations that cause PARK8-linked Parkinson's disease. Neuron. 2004; 44:595-600. [PubMed: 15541308]

Palacino JJ, Sagi D, Goldberg MS, Krauss S, Motz C, Wacker M, Klose J, Shen J. Mitochondrial dysfunction and oxidative damage in parkin-deficient mice. The Journal of biological chemistry. 2004; 279:18614-18622. [PubMed: 14985362]

Parihar MS, Parihar A, Fujita M, Hashimoto M, Ghafourifar P. Mitochondrial association of alphasynuclein causes oxidative stress. Cellular and molecular life sciences : CMLS. 2008; 65:12721284. [PubMed: 18322646]

Park J, Lee G, Chung J. The PINK1-Parkin pathway is involved in the regulation of mitochondrial remodeling process. Biochemical and biophysical research communications. 2009; 378:518-523. [PubMed: 19056353]

Park J, Lee SB, Lee S, Kim Y, Song S, Kim S, Bae E, Kim J, Shong M, Kim JM, Chung J. Mitochondrial dysfunction in Drosophila PINK1 mutants is complemented by parkin. Nature. 2006; 441:1157-1161. [PubMed: 16672980]

Parker WD Jr. Parks JK, Swerdlow RH. Complex I deficiency in Parkinson's disease frontal cortex. Brain research. 2008; 1189:215-218. [PubMed: 18061150]

Paterna JC, Leng A, Weber E, Feldon J, Bueler H. DJ-1 and Parkin modulate dopamine-dependent behavior and inhibit MPTP-induced nigral dopamine neuron loss in mice. Molecular therapy : the journal of the American Society of Gene Therapy. 2007; 15:698-704. [PubMed: 17299411]

Pennathur S, Jackson-Lewis V, Przedborski S, Heinecke JW. Mass spectrometric quantification of 3nitrotyrosine, ortho-tyrosine, and o,o'-dityrosine in brain tissue of 1-methyl-4-phenyl-1,2,3, 6tetrahydropyridine-treated mice, a model of oxidative stress in Parkinson's disease. The Journal of biological chemistry. 1999; 274:34621-34628. [PubMed: 10574926]

Perez FA, Palmiter RD. Parkin-deficient mice are not a robust model of parkinsonism. Proceedings of the National Academy of Sciences of the United States of America. 2005; 102:2174-2179. [PubMed: 15684050]

Perier C, Bove J, Wu DC, Dehay B, Choi DK, Jackson-Lewis V, Rathke-Hartlieb S, Bouillet P, Strasser A, Schulz JB, Przedborski S, Vila M. Two molecular pathways initiate mitochondriadependent dopaminergic neurodegeneration in experimental Parkinson's disease. Proceedings of the National Academy of Sciences of the United States of America. 2007; 104:8161-8166. [PubMed: 17483459]

Perier C, Tieu K, Guegan C, Caspersen C, Jackson-Lewis V, Carelli V, Martinuzzi A, Hirano M, Przedborski S, Vila M. Complex I deficiency primes Bax-dependent neuronal apoptosis through mitochondrial oxidative damage. Proceedings of the National Academy of Sciences of the United States of America. 2005; 102:19126-19131. [PubMed: 16365298]

Periquet M, Corti O, Jacquier S, Brice A. Proteomic analysis of parkin knockout mice: alterations in energy metabolism, protein handling and synaptic function. Journal of neurochemistry. 2005; 95:1259-1276. [PubMed: 16150055]

Pesah Y, Pham T, Burgess H, Middlebrooks B, Verstreken P, Zhou Y, Harding M, Bellen H, Mardon G. Drosophila parkin mutants have decreased mass and cell size and increased sensitivity to oxygen radical stress. Development. 2004; 131:2183-2194. [PubMed: 15073152]

Petit A, Kawarai T, Paitel E, Sanjo N, Maj M, Scheid M, Chen F, Gu Y, Hasegawa H, Salehi-Rad S, Wang L, Rogaeva E, Fraser P, Robinson B, St George-Hyslop P, Tandon A. Wild-type PINK1 prevents basal and induced neuronal apoptosis, a protective effect abrogated by Parkinson disease-related mutations. The Journal of biological chemistry. 2005; 280:34025-34032. [PubMed: 16079129]

Piao Y, Kim HG, Oh MS, Pak YK. Overexpression of TFAM, NRF-1 and myr-AKT protects the $\mathrm{MPP}(+)$-induced mitochondrial dysfunctions in neuronal cells. Biochimica et biophysica acta. 2012; 1820:577-585. [PubMed: 21856379]

Piccoli C, Sardanelli A, Scrima R, Ripoli M, Quarato G, D'Aprile A, Bellomo F, Scacco S, De Michele G, Filla A, Iuso A, Boffoli D, Capitanio N, Papa S. Mitochondrial respiratory dysfunction in familiar parkinsonism associated with PINK1 mutation. Neurochemical research. 2008; 33:25652574. [PubMed: 18473170] 
Ping HX, Shepard PD. Apamin-sensitive $\mathrm{Ca}(2+)$-activated $\mathrm{K}+$ channels regulate pacemaker activity in nigral dopamine neurons. Neuroreport. 1996; 7:809-814. [PubMed: 8733751]

Polymeropoulos MH, Lavedan C, Leroy E, Ide SE, Dehejia A, Dutra A, Pike B, Root H, Rubenstein J, Boyer R, Stenroos ES, Chandrasekharappa S, Athanassiadou A, Papapetropoulos T, Johnson WG, Lazzarini AM, Duvoisin RC, Di Iorio G, Golbe LI, Nussbaum RL. Mutation in the alphasynuclein gene identified in families with Parkinson's disease. Science. 1997; 276:2045-2047. [PubMed: 9197268]

Poole AC, Thomas RE, Andrews LA, McBride HM, Whitworth AJ, Pallanck LJ. The PINK1/Parkin pathway regulates mitochondrial morphology. Proceedings of the National Academy of Sciences of the United States of America. 2008; 105:1638-1643. [PubMed: 18230723]

Poon HF, Frasier M, Shreve N, Calabrese V, Wolozin B, Butterfield DA. Mitochondrial associated metabolic proteins are selectively oxidized in A30P alpha-synuclein transgenic mice--a model of familial Parkinson's disease. Neurobiology of disease. 2005; 18:492-498. [PubMed: 15755676]

Prasad K, Winnik B, Thiruchelvam MJ, Buckley B, Mirochnitchenko O, Richfield EK. Prolonged toxicokinetics and toxicodynamics of paraquat in mouse brain. Environmental health perspectives. 2007; 115:1448-1453. [PubMed: 17938734]

Pridgeon JW, Olzmann JA, Chin LS, Li L. PINK1 protects against oxidative stress by phosphorylating mitochondrial chaperone TRAP1. PLoS biology. 2007; 5:e172. [PubMed: 17579517]

Przedborski S, Jackson-Lewis V, Yokoyama R, Shibata T, Dawson VL, Dawson TM. Role of neuronal nitric oxide in 1-methyl-4-phenyl-1,2,3,6-tetrahydropyridine (MPTP)-induced dopaminergic neurotoxicity. Proceedings of the National Academy of Sciences of the United States of America. 1996; 93:4565-4571. [PubMed: 8643444]

Przedborski S, Kostic V, Jackson-Lewis V, Naini AB, Simonetti S, Fahn S, Carlson E, Epstein CJ, Cadet JL. Transgenic mice with increased $\mathrm{Cu} / \mathrm{Zn}$-superoxide dismutase activity are resistant to N-methyl-4-phenyl-1,2,3,6-tetrahydropyridine-induced neurotoxicity. The Journal of neuroscience : the official journal of the Society for Neuroscience. 1992; 12:1658-1667. [PubMed: 1578260]

Puopolo M, Raviola E, Bean BP. Roles of subthreshold calcium current and sodium current in spontaneous firing of mouse midbrain dopamine neurons. The Journal of neuroscience : the official journal of the Society for Neuroscience. 2007; 27:645-656. [PubMed: 17234596]

Ramsay RR, Salach JI, Dadgar J, Singer TP. Inhibition of mitochondrial NADH dehydrogenase by pyridine derivatives and its possible relation to experimental and idiopathic parkinsonism. Biochemical and biophysical research communications. 1986; 135:269-275. [PubMed: 3485428]

Reddy PH, Reddy TP, Manczak M, Calkins MJ, Shirendeb U, Mao P. Dynamin-related protein 1 and mitochondrial fragmentation in neurodegenerative diseases. Brain research reviews. 2011; 67:103-118. [PubMed: 21145355]

Reeve AK, Krishnan KJ, Turnbull D. Mitochondrial DNA mutations in disease, aging, and neurodegeneration. Annals of the New York Academy of Sciences. 2008; 1147:21-29. [PubMed: 19076427]

Richardson JR, Quan Y, Sherer TB, Greenamyre JT, Miller GW. Paraquat neurotoxicity is distinct from that of MPTP and rotenone. Toxicological sciences : an official journal of the Society of Toxicology. 2005; 88:193-201. [PubMed: 16141438]

Richter C, Park JW, Ames BN. Normal oxidative damage to mitochondrial and nuclear DNA is extensive. Proceedings of the National Academy of Sciences of the United States of America. 1988; 85:6465-6467. [PubMed: 3413108]

Ritz B, Rhodes SL, Bordelon Y, Bronstein J. alpha-Synuclein genetic variants predict faster motor symptom progression in idiopathic Parkinson disease. PloS one. 2012; 7:e36199. [PubMed: 22615757]

Ritz BR, Manthripragada AD, Costello S, Lincoln SJ, Farrer MJ, Cockburn M, Bronstein J. Dopamine transporter genetic variants and pesticides in Parkinson's disease. Environmental health perspectives. 2009; 117:964-969. [PubMed: 19590691]

Roede JR, Hansen JM, Go YM, Jones DP. Maneb and paraquat-mediated neurotoxicity: involvement of peroxiredoxin/thioredoxin system. Toxicological sciences : an official journal of the Society of Toxicology. 2011; 121:368-375. [PubMed: 21402726] 
Romo R, Schultz W. Dopamine neurons of the monkey midbrain: contingencies of responses to active touch during self-initiated arm movements. Journal of neurophysiology. 1990; 63:592-606. [PubMed: 2329363]

Rosen KM, Veereshwarayya V, Moussa CE, Fu Q, Goldberg MS, Schlossmacher MG, Shen J, Querfurth HW. Parkin protects against mitochondrial toxins and beta-amyloid accumulation in skeletal muscle cells. The Journal of biological chemistry. 2006; 281:12809-12816. [PubMed: 16517603]

Saini N, Oelhafen S, Hua H, Georgiev O, Schaffner W, Bueler H. Extended lifespan of Drosophila parkin mutants through sequestration of redox-active metals and enhancement of anti-oxidative pathways. Neurobiology of disease. 2010; 40:82-92. [PubMed: 20483372]

Saint-Pierre M, Tremblay ME, Sik A, Gross RE, Cicchetti F. Temporal effects of paraquat/maneb on microglial activation and dopamine neuronal loss in older rats. Journal of neurochemistry. 2006; 98:760-772. [PubMed: 16893418]

Schapira, AH. The Mount Sinai journal of medicine. Vol. 78. New York: 2011. Mitochondrial pathology in Parkinson's disease; p. 872-881.

Schapira AH, Cooper JM, Dexter D, Clark JB, Jenner P, Marsden CD. Mitochondrial complex I deficiency in Parkinson's disease. Journal of neurochemistry. 1990; 54:823-827. [PubMed: 2154550]

Schon EA, Przedborski S. Mitochondria: the next (neurode)generation. Neuron. 2011; 70:1033-1053. [PubMed: 21689593]

Shavali S, Brown-Borg HM, Ebadi M, Porter J. Mitochondrial localization of alpha-synuclein protein in alpha-synuclein overexpressing cells. Neuroscience letters. 2008; 439:125-128. [PubMed: 18514418]

Sherer TB, Betarbet R, Testa CM, Seo BB, Richardson JR, Kim JH, Miller GW, Yagi T, MatsunoYagi A, Greenamyre JT. Mechanism of toxicity in rotenone models of Parkinson's disease. The Journal of neuroscience : the official journal of the Society for Neuroscience. 2003; 23:1075610764. [PubMed: 14645467]

Shimizu K, Matsubara K, Ohtaki K, Fujimaru S, Saito O, Shiono H. Paraquat induces long-lasting dopamine overflow through the excitotoxic pathway in the striatum of freely moving rats. Brain research. 2003; 976:243-252. [PubMed: 12763259]

Shimura H, Hattori N, Kubo S, Mizuno Y, Asakawa S, Minoshima S, Shimizu N, Iwai K, Chiba T, Tanaka K, Suzuki T. Familial Parkinson disease gene product, parkin, is a ubiquitin-protein ligase. Nature genetics. 2000; 25:302-305. [PubMed: 10888878]

Shults CW, Beal MF, Fontaine D, Nakano K, Haas RH. Absorption, tolerability, and effects on mitochondrial activity of oral coenzyme Q10 in parkinsonian patients. Neurology. 1998; 50:793795. [PubMed: 9521279]

Silva BA, Breydo L, Fink AL, Uversky VN. Agrochemicals, alpha-Synuclein, and Parkinson's Disease. Molecular neurobiology. 2012

Silvestri L, Caputo V, Bellacchio E, Atorino L, Dallapiccola B, Valente EM, Casari G. Mitochondrial import and enzymatic activity of PINK1 mutants associated to recessive parkinsonism. Human molecular genetics. 2005; 14:3477-3492. [PubMed: 16207731]

Singleton AB, Farrer M, Johnson J, Singleton A, Hague S, Kachergus J, Hulihan M, Peuralinna T, Dutra A, Nussbaum R, Lincoln S, Crawley A, Hanson M, Maraganore D, Adler C, Cookson MR, Muenter M, Baptista M, Miller D, Blancato J, Hardy J, Gwinn-Hardy K. alpha-Synuclein locus triplication causes Parkinson's disease. Science. 2003; 302:841. [PubMed: 14593171]

Smith WW, Pei Z, Jiang H, Dawson VL, Dawson TM, Ross CA. Kinase activity of mutant LRRK2 mediates neuronal toxicity. Nature neuroscience. 2006; 9:1231-1233.

Song DD, Shults CW, Sisk A, Rockenstein E, Masliah E. Enhanced substantia nigra mitochondrial pathology in human alpha-synuclein transgenic mice after treatment with MPTP. Experimental neurology. 2004; 186:158-172. [PubMed: 15026254]

Sonia Angeline M, Chaterjee P, Anand K, Ambasta RK, Kumar P. Rotenone-induced parkinsonism elicits behavioral impairments and differential expression of parkin, heat shock proteins and caspases in the rat. Neuroscience. 2012; 220:291-301. [PubMed: 22710069] 
Soubannier V, McBride HM. Positioning mitochondrial plasticity within cellular signaling cascades. Biochimica et biophysica acta. 2009; 1793:154-170. [PubMed: 18694785]

Spillantini MG, Goedert M. The alpha-synucleinopathies: Parkinson's disease, dementia with Lewy bodies, and multiple system atrophy. Annals of the New York Academy of Sciences. 2000; 920:16-27. [PubMed: 11193145]

Spillantini MG, Schmidt ML, Lee VM, Trojanowski JQ, Jakes R, Goedert M. Alpha-synuclein in Lewy bodies. Nature. 1997; 388:839-840. [PubMed: 9278044]

Starkov AA. The role of mitochondria in reactive oxygen species metabolism and signaling. Annals of the New York Academy of Sciences. 2008; 1147:37-52. [PubMed: 19076429]

Sterky FH, Hoffman AF, Milenkovic D, Bao B, Paganelli A, Edgar D, Wibom R, Lupica CR, Olson L, Larsson NG. Altered dopamine metabolism and increased vulnerability to MPTP in mice with partial deficiency of mitochondrial complex I in dopamine neurons. Human molecular genetics. 2012; 21:1078-1089. [PubMed: 22090423]

Storch A, Jost WH, Vieregge P, Spiegel J, Greulich W, Durner J, Muller T, Kupsch A, Henningsen H, Oertel WH, Fuchs G, Kuhn W, Niklowitz P, Koch R, Herting B, Reichmann H. Randomized, double-blind, placebo-controlled trial on symptomatic effects of coenzyme Q(10) in Parkinson disease. Archives of neurology. 2007; 64:938-944. [PubMed: 17502459]

Sun Y, Vashisht AA, Tchieu J, Wohlschlegel JA, Dreier L. Voltage-dependent anion channels (VDACs) recruit Parkin to defective mitochondria to promote mitochondrial autophagy. The Journal of biological chemistry. 2012; 287:40652-40660. [PubMed: 23060438]

Surmeier DJ. Calcium, ageing, and neuronal vulnerability in Parkinson's disease. Lancet neurology. 2007; 6:933-938. [PubMed: 17884683]

Surmeier DJ, Guzman JN, Sanchez-Padilla J, Schumacker PT. The role of calcium and mitochondrial oxidant stress in the loss of substantia nigra pars compacta dopaminergic neurons in Parkinson's disease. Neuroscience. 2011; 198:221-231. [PubMed: 21884755]

Swerdlow RH, Parks JK, Cassarino DS, Binder DR, Bennett JP Jr. Di Iorio G, Golbe LI, Parker WD Jr. Biochemical analysis of cybrids expressing mitochondrial DNA from Contursi kindred Parkinson's subjects. Experimental neurology. 2001; 169:479-485. [PubMed: 11358461]

Taira T, Saito Y, Niki T, Iguchi-Ariga SM, Takahashi K, Ariga H. DJ-1 has a role in antioxidative stress to prevent cell death. EMBO reports. 2004; 5:213-218. [PubMed: 14749723]

Tanaka Y, Engelender S, Igarashi S, Rao RK, Wanner T, Tanzi RE, Sawa A, V LD, Dawson TM, Ross CA. Inducible expression of mutant alpha-synuclein decreases proteasome activity and increases sensitivity to mitochondria-dependent apoptosis. Human molecular genetics. 2001; 10:919-926. [PubMed: 11309365]

Tang B, Xiong H, Sun P, Zhang Y, Wang D, Hu Z, Zhu Z, Ma H, Pan Q, Xia JH, Xia K, Zhang Z. Association of PINK1 and DJ-1 confers digenic inheritance of early-onset Parkinson's disease. Human molecular genetics. 2006; 15:1816-1825. [PubMed: 16632486]

Tanner CM, Kamel F, Ross GW, Hoppin JA, Goldman SM, Korell M, Marras C, Bhudhikanok GS, Kasten M, Chade AR, Comyns K, Richards MB, Meng C, Priestley B, Fernandez HH, Cambi F, Umbach DM, Blair A, Sandler DP, Langston JW. Rotenone, paraquat, and Parkinson's disease. Environmental health perspectives. 2011; 119:866-872. [PubMed: 21269927]

Thiruchelvam M, Prokopenko O, Cory-Slechta DA, Buckley B, Mirochnitchenko O. Overexpression of superoxide dismutase or glutathione peroxidase protects against the paraquat + maneb-induced Parkinson disease phenotype. The Journal of biological chemistry. 2005; 280:22530-22539. [PubMed: 15824117]

Thiruchelvam M, Richfield EK, Goodman BM, Baggs RB, Cory-Slechta DA. Developmental exposure to the pesticides paraquat and maneb and the Parkinson's disease phenotype. Neurotoxicology. 2002; 23:621-633. [PubMed: 12428734]

Thomas B, Beal MF. Parkinson's disease. Human molecular genetics 16 Spec No. 2007; 2:R183R194.

Twig G, Elorza A, Molina AJ, Mohamed H, Wikstrom JD, Walzer G, Stiles L, Haigh SE, Katz S, Las G, Alroy J, Wu M, Py BF, Yuan J, Deeney JT, Corkey BE, Shirihai OS. Fission and selective fusion govern mitochondrial segregation and elimination by autophagy. The EMBO journal. 2008; 27:433-446. [PubMed: 18200046] 
Uversky VN. Neuropathology, biochemistry, and biophysics of alpha-synuclein aggregation. Journal of neurochemistry. 2007; 103:17-37. [PubMed: 17623039]

Valente EM, Abou-Sleiman PM, Caputo V, Muqit MM, Harvey K, Gispert S, Ali Z, Del Turco D, Bentivoglio AR, Healy DG, Albanese A, Nussbaum R, Gonzalez-Maldonado R, Deller T, Salvi S, Cortelli P, Gilks WP, Latchman DS, Harvey RJ, Dallapiccola B, Auburger G, Wood NW. Hereditary early-onset Parkinson's disease caused by mutations in PINK1. Science. 2004; 304:1158-1160. [PubMed: 15087508]

Van Remmen H, Qi W, Sabia M, Freeman G, Estlack L, Yang H, Mao Guo Z, Huang TT, Strong R, Lee S, Epstein CJ, Richardson A. Multiple deficiencies in antioxidant enzymes in mice result in a compound increase in sensitivity to oxidative stress. Free radical biology \& medicine. 2004; 36:1625-1634. [PubMed: 15182862]

Varastet M, Riche D, Maziere M, Hantraye P. Chronic MPTP treatment reproduces in baboons the differential vulnerability of mesencephalic dopaminergic neurons observed in Parkinson's disease. Neuroscience. 1994; 63:47-56. [PubMed: 7898660]

Vercammen L, Van der Perren A, Vaudano E, Gijsbers R, Debyser Z, Van den Haute C, Baekelandt V. Parkin protects against neurotoxicity in the 6-hydroxydopamine rat model for Parkinson's disease. Molecular therapy : the journal of the American Society of Gene Therapy. 2006; 14:716-723. [PubMed: 16914382]

Vives-Bauza C, Andreu AL, Manfredi G, Beal MF, Janetzky B, Gruenewald TH, Lin MT. Sequence analysis of the entire mitochondrial genome in Parkinson's disease. Biochemical and biophysical research communications. 2002; 290:1593-1601. [PubMed: 11820805]

Wang HL, Chou AH, Wu AS, Chen SY, Weng YH, Kao YC, Yeh TH, Chu PJ, Lu CS. PARK6 PINK1 mutants are defective in maintaining mitochondrial membrane potential and inhibiting ROS formation of substantia nigra dopaminergic neurons. Biochimica et biophysica acta. 2011; 1812:674-684. [PubMed: 21421046]

Wang HL, Chou AH, Yeh TH, Li AH, Chen YL, Kuo YL, Tsai SR, Yu ST. PINK1 mutants associated with recessive Parkinson's disease are defective in inhibiting mitochondrial release of cytochrome c. Neurobiology of disease. 2007; 28:216-226. [PubMed: 17707122]

Wang XF, Li S, Chou AP, Bronstein JM. Inhibitory effects of pesticides on proteasome activity: implication in Parkinson's disease. Neurobiology of disease. 2006; 23:198-205. [PubMed: 16626962]

Wang Y, Shi M, Chung KA, Zabetian CP, Leverenz JB, Berg D, Srulijes K, Trojanowski JQ, Lee VM, Siderowf AD, Hurtig H, Litvan I, Schiess MC, Peskind ER, Masuda M, Hasegawa M, Lin X, Pan C, Galasko D, Goldstein DS, Jensen PH, Yang H, Cain KC, Zhang J. Phosphorylated alphasynuclein in Parkinson's disease. Science translational medicine. 2012; 4 121ra120.

Wen Y, Li W, Poteet EC, Xie L, Tan C, Yan LJ, Ju X, Liu R, Qian H, Marvin MA, Goldberg MS, She H, Mao Z, Simpkins JW, Yang SH. Alternative mitochondrial electron transfer as a novel strategy for neuroprotection. The Journal of biological chemistry. 2011; 286:16504-16515. [PubMed: 21454572]

West AB, Moore DJ, Biskup S, Bugayenko A, Smith WW, Ross CA, Dawson VL, Dawson TM. Parkinson's disease-associated mutations in leucine-rich repeat kinase 2 augment kinase activity. Proceedings of the National Academy of Sciences of the United States of America. 2005; 102:16842-16847. [PubMed: 16269541]

Wilson CJ, Callaway JC. Coupled oscillator model of the dopaminergic neuron of the substantia nigra. Journal of neurophysiology. 2000; 83:3084-3100. [PubMed: 10805703]

Winklhofer KF, Haass C. Mitochondrial dysfunction in Parkinson's disease. Biochimica et biophysica acta. 2010; 1802:29-44. [PubMed: 19733240]

Winklhofer KF, Tatzelt J, Haass C. The two faces of protein misfolding: gain- and loss-of-function in neurodegenerative diseases. The EMBO journal. 2008; 27:336-349. [PubMed: 18216876]

Wood-Kaczmar A, Gandhi S, Yao Z, Abramov AY, Miljan EA, Keen G, Stanyer L, Hargreaves I, Klupsch K, Deas E, Downward J, Mansfield L, Jat P, Taylor J, Heales S, Duchen MR, Latchman D, Tabrizi SJ, Wood NW. PINK1 is necessary for long term survival and mitochondrial function in human dopaminergic neurons. PloS one. 2008; 3:e2455. [PubMed: 18560593] 
Wu BL, Song B, Tian SZ, Huo SH, Cui CX, Guo YS, Liu HJ. Central nervous system damage due to acute paraquat poisoning: A neuroimaging study with 3.0T MRI. Neurotoxicology. 2012

Yang W, Chen L, Ding Y, Zhuang X, Kang UJ. Paraquat induces dopaminergic dysfunction and proteasome impairment in DJ-1-deficient mice. Human molecular genetics. 2007; 16:2900-2910. [PubMed: 17823202]

Yang W, Tiffany-Castiglioni E. The bipyridyl herbicide paraquat produces oxidative stress-mediated toxicity in human neuroblastoma SH-SY5Y cells: relevance to the dopaminergic pathogenesis. Journal of toxicology and environmental health Part A. 2005; 68:1939-1961. [PubMed: 16263688]

Yang Y, Gehrke S, Imai Y, Huang Z, Ouyang Y, Wang JW, Yang L, Beal MF, Vogel H, Lu B. Mitochondrial pathology and muscle and dopaminergic neuron degeneration caused by inactivation of Drosophila Pink1 is rescued by Parkin. Proceedings of the National Academy of Sciences of the United States of America. 2006; 103:10793-10798. [PubMed: 16818890]

Yang Y, Ouyang Y, Yang L, Beal MF, McQuibban A, Vogel H, Lu B. Pink1 regulates mitochondrial dynamics through interaction with the fission/fusion machinery. Proceedings of the National Academy of Sciences of the United States of America. 2008; 105:7070-7075. [PubMed: 18443288]

Yokota T, Sugawara K, Ito K, Takahashi R, Ariga H, Mizusawa H. Down regulation of DJ-1 enhances cell death by oxidative stress, ER stress, and proteasome inhibition. Biochemical and biophysical research communications. 2003; 312:1342-1348. [PubMed: 14652021]

Yoshino H, Nakagawa-Hattori Y, Kondo T, Mizuno Y. Mitochondrial complex I and II activities of lymphocytes and platelets in Parkinson's disease. Journal ofneural transmission Parkinson's disease and dementia section. 1992; 4:27-34.

Yu W, Sun Y, Guo S, Lu B. The PINK1/Parkin pathway regulates mitochondrial dynamics and function in mammalian hippocampal and dopaminergic neurons. Human molecular genetics. 2011; 20:3227-3240. [PubMed: 21613270]

Yumino K, Kawakami I, Tamura M, Hayashi T, Nakamura M. Paraquat- and diquat-induced oxygen radical generation and lipid peroxidation in rat brain microsomes. Journal of biochemistry. 2002; 131:565-570. [PubMed: 11926994]

Zarranz JJ, Alegre J, Gomez-Esteban JC, Lezcano E, Ros R, Ampuero I, Vidal L, Hoenicka J, Rodriguez O, Atares B, Llorens V, Gomez Tortosa E, del Ser T, Munoz DG, de Yebenes JG. The new mutation, E46K, of alpha-synuclein causes Parkinson and Lewy body dementia. Annals of neurology. 2004; 55:164-173. [PubMed: 14755719]

Zhang J, Fitsanakis VA, Gu G, Jing D, Ao M, Amarnath V, Montine TJ. Manganese ethylene-bisdithiocarbamate and selective dopaminergic neurodegeneration in rat: a link through mitochondrial dysfunction. Journal of neurochemistry. 2003; 84:336-346. [PubMed: 12558996]

Zhang L, Shimoji M, Thomas B, Moore DJ, Yu SW, Marupudi NI, Torp R, Torgner IA, Ottersen OP, Dawson TM, Dawson VL. Mitochondrial localization of the Parkinson's disease related protein DJ-1: implications for pathogenesis. Human molecular genetics. 2005; 14:2063-2073. [PubMed: 15944198]

Zhang L, Zhang C, Zhu Y, Cai Q, Chan P, Ueda K, Yu S, Yang H. Semi-quantitative analysis of alpha-synuclein in subcellular pools of rat brain neurons: an immunogold electron microscopic study using a C-terminal specific monoclonal antibody. Brain research. 2008; 1244:40-52. [PubMed: 18817762]

Zhang X, Zhou JY, Chin MH, Schepmoes AA, Petyuk VA, Weitz KK, Petritis BO, Monroe ME, Camp DG, Wood SA, Melega WP, Bigelow DJ, Smith DJ, Qian WJ, Smith RD. Region-specific protein abundance changes in the brain of MPTP-induced Parkinson's disease mouse model. Journal of proteome research. 2010; 9:1496-1509. [PubMed: 20155936]

Zhong N, Xu J. Synergistic activation of the human MnSOD promoter by DJ-1 and PGC-1alpha: regulation by SUMOylation and oxidation. Human molecular genetics. 2008; 17:3357-3367. [PubMed: 18689799]

Zhou Y, Shie FS, Piccardo P, Montine TJ, Zhang J. Proteasomal inhibition induced by manganese ethylene-bis-dithiocarbamate: relevance to Parkinson's disease. Neuroscience. 2004; 128:281291. [PubMed: 15350641] 
Zhu C, Vourc'h P, Fernagut PO, Fleming SM, Lacan S, Dicarlo CD, Seaman RL, Chesselet MF. Variable effects of chronic subcutaneous administration of rotenone on striatal histology. The Journal of comparative neurology. 2004; 478:418-426. [PubMed: 15384065]

Zimprich A, Biskup S, Leitner P, Lichtner P, Farrer M, Lincoln S, Kachergus J, Hulihan M, Uitti RJ, Calne DB, Stoessl AJ, Pfeiffer RF, Patenge N, Carbajal IC, Vieregge P, Asmus F, MullerMyhsok B, Dickson DW, Meitinger T, Strom TM, Wszolek ZK, Gasser T. Mutations in LRRK2 cause autosomal-dominant parkinsonism with pleomorphic pathology. Neuron. 2004; 44:601607. [PubMed: 15541309]

Zorzano A, Liesa M, Sebastian D, Segales J, Palacin M. Mitochondrial fusion proteins: dual regulators of morphology and metabolism. Seminars in cell \& developmental biology. 2010; 21:566-574. [PubMed: 20079867] 


\section{Highlights}

- We summarize the mitochondrial respiratory chain defects and mtDNA mutations that are affected in PD.

- We outline the effects of environmental toxins on mitochondrial function in PD.

- We narrate the mitochondrial dysfunction associated with monogenic PD 
Table 1

Summary of mitochondrial dysfunction caused by environmental toxins used to model PD

\begin{tabular}{|c|c|c|}
\hline Toxin & Mitochondrial dysfunction & Reference \\
\hline $\begin{array}{l}\text { MPP+/ } \\
\text { MPTP }\end{array}$ & 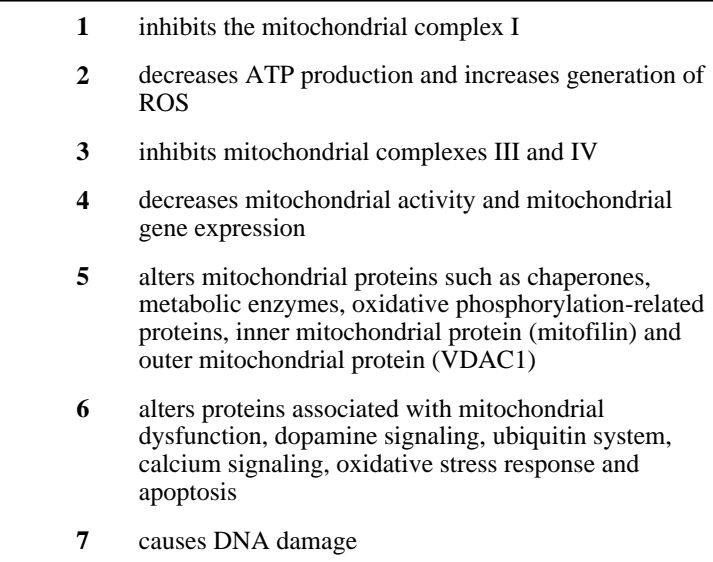 & $\begin{array}{ll}\mathbf{1} & \text { (Nicklas et al., 1985, Ramsay et al., 1986) } \\
\mathbf{2} & \begin{array}{l}\text { (Hasegawa et al., 1990, Chan et al., 1991, } \\
\text { Hantraye et al., 1996, Przedborski et al., 1996, } \\
\end{array} \\
\text { Fabre et al., 1999, Pennathur et al., 1999) } \\
\mathbf{3} & \text { (Desai et al., 1996) } \\
\mathbf{4} & \text { (Piao et al., 2012) } \\
\mathbf{5} & \text { (Burte et al., 2011) } \\
\mathbf{6} & \text { (Zhang et al., 2010) } \\
\mathbf{7} & \text { (Hoang et al., 2009) }\end{array}$ \\
\hline Rotenone & reduces complex I activity & (Betarbet et al., 2000) \\
\hline Paraquat & $\begin{array}{l}\mathbf{1} \text { accumulates in mitochondria } \\
\mathbf{2} \text { acts as a potent redox cycler which converts free } \\
\text { radicals that interact with molecular oxygen to } \\
\text { superoxide and other ROS }\end{array}$ & $\begin{array}{ll}1 & \text { (Cocheme and Murphy, 2008) } \\
\mathbf{2} & \text { (Jones and Vale, 2000, Yumino et al., 2002) } \\
\text { (Thiruchelvam et al., 2005) (Mollace et al., } \\
\text { 2003) }\end{array}$ \\
\hline Maneb & inhibits mitochondrial complex III & (Zhang et al., 2003) \\
\hline
\end{tabular}


Table 2

Summary of mitochondrial dysfunction in familial PD

\begin{tabular}{|c|c|c|c|c|}
\hline Gene & \multicolumn{2}{|c|}{ Mitochondrial dysfunction } & \multicolumn{2}{|c|}{ Reference } \\
\hline $\begin{array}{l}\text { a-synuclein } \\
(P A R K 1, \\
S N C A) \\
\text { (A53T or } \\
\text { overexpress } \\
\text { ion) }\end{array}$ & $\begin{array}{l}1 \\
2 \\
3 \\
4 \\
5 \\
6 \\
7\end{array}$ & $\begin{array}{l}\text { causes accumulation of a-synuclein in mitochondria in } \\
\text { specific regions } \\
\text { mutant A53T human a-synuclein gene in mice causes } \\
\text { mtDNA damage and respiratory complex IV impairment } \\
\text { overexpression of wild-type human a- synuclein increases } \\
\text { mitochondrial pathology in nigrostriatal dopaminergic } \\
\text { neurons when exposed to low doses of MPTP } \\
\text { mutant A53T human a-synuclein gene in cell lines reduces } \\
\text { mitochondrial complex I activity } \\
\text { mutant A53T human a-synuclein gene in mice increases } \\
\text { sensitivity to mitochondrial toxins such as MPTP and } \\
\text { paraquat } \\
\text { overexpression of mutant A53T or wild-type human a- } \\
\text { synuclein in cell lines causes mitochondrial association and } \\
\text { leads to cytochrome c release, enhanced mitochondrial } \\
\text { calcium and nitric oxide, and oxidative modification of } \\
\text { mitochondrial components } \\
\text { mitochondria of PD patients show accumulation of a- } \\
\text { synuclein in substantia nigra and striatum, and decreased } \\
\text { complex I activity }\end{array}$ & $\begin{array}{l}2 \\
3 \\
4 \\
5\end{array}$ & $\begin{array}{l}\text { (Li et al., 2007, Nakamura et al., } \\
\text { 2008, Shavali et al., 2008, Zhang } \\
\text { et al., 2008) } \\
\text { (Martin et al., 2006) } \\
\text { (Song et al., 2004) } \\
\text { (Butler et al., 2012) } \\
\text { (Norris et al., 2007, Thomas and } \\
\text { Beal, 2007) } \\
\text { (Parihar et al., 2008) } \\
\text { (Devi et al., 2008) }\end{array}$ \\
\hline $\begin{array}{l}\text { Parkin } \\
(P A R K 2)\end{array}$ & $\begin{array}{l}2 \\
3 \\
4 \\
5 \\
6 \\
7\end{array}$ & $\begin{array}{l}\text { localizes in mitochondria where it binds to mitochondrial } \\
\text { transcription factor (TFAM) to regulate mitochondrial } \\
\text { transcription and replication } \\
\text { overexpression prevents ceramide-induced mitochondrial } \\
\text { swelling and cytochrome c release } \\
\text { knockout mice have reduced mitochondrial complex I and } \\
\text { IV activity } \\
\text { homozygous parkin mutations in humans impair } \\
\text { mitochondrial complex I and complex IV activities in } \\
\text { leukocytes } \\
\text { mice lacking parkin gene increases sensitivity to } \\
\text { mitochondrial toxin, rotenone } \\
\text { critical for mitochondrial dynamics and autophagy } \\
\text { PINK1-parkin pathway promotes mitochondrial fission/ } \\
\text { fusion and controls mitochondrial dynamics }\end{array}$ & $\begin{array}{l}1 \\
2 \\
3 \\
4 \\
5 \\
6\end{array}$ & $\begin{array}{l}\text { (Kuroda et al., 2006) } \\
\text { (Darios et al., 2003) } \\
\text { (Palacino et al., 2004) } \\
\text { (Muftuoglu et al., 2004) } \\
\text { (Rosen et al., 2006) } \\
\text { (Narendra et al., 2008, Sun et al. } \\
\text { 2012) } \\
\text { (Clark et al., 2006, Deng et al., } \\
\text { 2008) (Poole et al., 2008, Yang } \\
\text { et al., 2008, Park et al., 2009, Yu } \\
\text { et al., 2011) }\end{array}$ \\
\hline $\begin{array}{l}\text { PINK1 } \\
(P A R K \sigma)\end{array}$ & $\begin{array}{l}3 \\
4 \\
5 \\
6\end{array}$ & $\begin{array}{l}\text { sub-localized in different regions including inner } \\
\text { mitochondrial membrane, intermembrane space and outer } \\
\text { mitochondrial membrane } \\
\text { PINK1 knockout mice and human dopaminergic neurons } \\
\text { have abnormalities in mitochondrial morphology, reduced } \\
\text { membrane potential, increased ROS generation and high } \\
\text { sensitivity to apoptosis } \\
\text { PINK1 KO mice fibroblasts show low mitochondrial } \\
\text { membrane potential, reduced cellular ATP levels and decline } \\
\text { in mitochondrial respiratory activity } \\
\text { PINK1 deficient mice showed reduction in complex I-IV } \\
\text { activity } \\
\text { PINK1 knockout mice show region-dependent alterations in } \\
\text { mitochondrial proteins related to energy metabolism and } \\
\text { membrane potential } \\
\text { lack of PINK1 in Drosophila results in abnormal } \\
\text { mitochondrial morphology, loss of nigrostriatal }\end{array}$ & $\begin{array}{l}2 \\
3 \\
4 \\
5 \\
6 \\
7 \\
8 \\
9\end{array}$ & $\begin{array}{l}\text { (Silvestri et al., 2005, Gandhi et } \\
\text { al., 2006, Pridgeon et al., 2007) } \\
\text { (Wood-Kaczmar et al., 2008) } \\
\text { (Amo et al., 2011) (Exner et al., } \\
\text { 2007) } \\
\text { (Gautier et al., 2008) } \\
\text { (Diedrich et al., 2011) } \\
\text { (Clark et al., 2006, Park et al., } \\
\text { 2006, Yang et al.,2006) } \\
\text { (Hoepken et al., 2007)(Piccoli et } \\
\text { al., 2008). } \\
\text { (Wang et al., 2011) } \\
\text { (Petit et al., 2005, Wang et al., } \\
\text { 2007) }\end{array}$ \\
\hline
\end{tabular}




\begin{tabular}{|c|c|c|c|c|}
\hline Gene & Mitocho & drial dysfunction & Reference & \\
\hline & $\begin{array}{l}7 \\
8 \\
9 \\
10\end{array}$ & $\begin{array}{l}\text { dopaminergic neurons, apoptotic muscle degeneration and } \\
\text { enhances vulnerability to oxidative stress } \\
\text { Loss causes mitochondrial defects, respiratory chain } \\
\text { abnormalities and ATP synthesis defects in human } \\
\text { peripheral tissues } \\
\text { overexpression of PINK1 in restores normal mitochondrial } \\
\text { morphology and inhibits ROS production } \\
\text { overexpression of wild type PINK1 inhibits mitochondrial } \\
\text { cytochrome c release and prevents neuronal apoptosis } \\
\text { PINK1-parkin pathway promotes mitochondrial fission/ } \\
\text { fusion and controls mitochondrial dynamics }\end{array}$ & 10 & $\begin{array}{l}\text { (Clark et al., 2006, Deng et al., } \\
\text { 2008) (Poole et al., 2008, Yang } \\
\text { et al., 2008, Park et al., 2009, Yu } \\
\text { et al., 2011) }\end{array}$ \\
\hline $\begin{array}{l}\text { DJ-1 } \\
(P A R K\rceil)\end{array}$ & $\begin{array}{l}1 \\
2 \\
3 \\
4 \\
4\end{array}$ & $\begin{array}{l}\text { DJ-1 knockout mice display a reduction in mitochondrial } \\
\text { transmembrane potential and an increase in mitochondrial } \\
\text { permeability transition pore opening } \\
\text { DJ-1 null dopaminergic neurons show deficiency in } \\
\text { mitochondrial complex I activity } \\
\text { DJ-1 mutation cause impaired mitochondrial respiration, } \\
\text { enhanced intra-mitochondrial ROS, reduced mitochondrial } \\
\text { membrane potential, altered mitochondrial morphology and } \\
\text { importantly, accumulation of defective mitochondria } \\
\text { DJ-1 may support mitochondrial function during oxidative } \\
\text { stress by interacting with several targets such as PINK1 and } \\
\text { parkin } \\
\text { DJ-1 activates transcription of Mn-SOD gene, which } \\
\text { encodes for the mitochondrial antioxidant enzyme }\end{array}$ & $\begin{array}{l}1 \\
2 \\
3 \\
4 \\
5\end{array}$ & $\begin{array}{l}\text { (Giaime et al., 2012) } \\
\text { (Heo et al., 2012)(Kwon et al., } \\
2011 \text { ) } \\
\text { (Krebiehl et al., 2010) } \\
\text { (Tang et al., 2006) (Moore et al., } \\
2005 \text { ) } \\
\text { (Zhong and Xu, 2008) }\end{array}$ \\
\hline LRRK2 (PARK 8$)$ & $\begin{array}{l}1 \\
2 \\
3\end{array}$ & $\begin{array}{l}\text { LRRK2 binds to outer mitochondrial membrane } \\
\text { LRRK2 G2019S mutation causes defects in mitochondrial } \\
\text { morphology and dynamics } \\
\text { PD patients carrying LRRK2 G2019S mutation show a } \\
\text { decrease in mitochondrial membrane potential and low total } \\
\text { intracellular ATP levels in addition to mitochondrial } \\
\text { elongation and interconnectivity }\end{array}$ & $\begin{array}{l}1 \\
2 \\
3\end{array}$ & $\begin{array}{l}\text { (West et al., 2005, Biskup et al., } \\
\text { 2006, Gloeckner et al., 2006) } \\
\text { (Niu et al., 2012) } \\
\text { (Mortiboys et al., 2010) }\end{array}$ \\
\hline
\end{tabular}

Please note all of the abbreviations are expanded when it appears first time in the text. 